\section{To: (Receiving Organization) Lockheed Mart in Hanford Company}

5. Proj./Prog./Dept./Div.:
3. From: (Originating Organization)

Environmental \& Nuclear

Initiatives, Specialty Engineering

6. Design Authority/ Design Agent/Cog. Engr .:
4. Related EDT No.:

7. Purchase order No.:

9. Equip./Component No.:

10. Systen/Bldg./Facility:

12. Major Assm. Dwg. No.:

13. Permit/Permit Application No.:

14. Required Response Date:

$\mathrm{N} / \mathrm{A}$

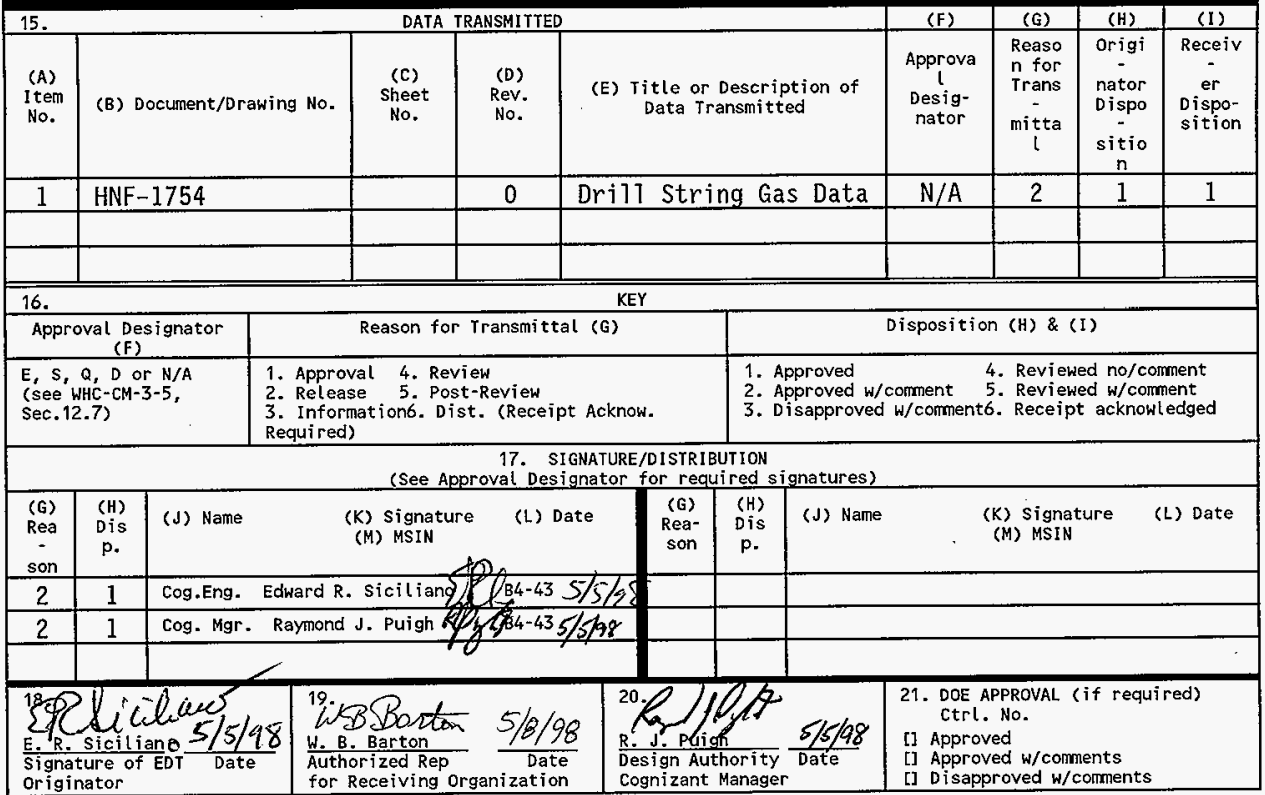

BD-7400-172-2 (05/96) GEF097 
HNF-1754, Rev. 0

\section{DRILL STRING GAS DATA}

Edward R. Siciliano

Fluor Daniel Northwest, Inc., Richland, WA 99352

U.S. Department of Energy Contract DE-AC06-96RL13200

EDT/ECN: 623003

Org Code: 04E00/403

B\&R Code:
UC:

Charge Code: N22DB

Total Pages: 40

Key Words:

KN

Dri11 String Data, Flammable Gas, Hanford Tanks, Retained gas, TWRS

Abstract:

Data and supporting documentation were compiled and analyzed for 26 cases of gas grab samples taken during waste-tank core sampling activities between September 1, 1995 and December 31, 1997. These cases were tested against specific criteria to reduce uncertainties associated with in-tank sampling location and conditions. Of the 26 possible cases, 16 qualified as dri11string grab samples most likely to represent recently released waste gases. The data from these 16 "confirmed" cases were further adjusted to remove non-waste gas contributions from coresampling activities (argon or nitrogen purge), the atmospheric "background", and laboratory sampler preparation (helium).

TRADEMARK DISCLAIMER. Reference herein to any specific comercial product, process, or service by trade name, trademark, manufacturer, or otherwise, does not necessarily constitute or imply its endorsement, recommendation, or favoring by the United States Government or any agency thereof or its contractors or subcontractors.

Printed in the United States of America. To obtain copies of this document, contact: Document Control Services, P.0. Box 950, Mailstop H6-08, Richland WA 99352, Phone (509) 372-2420; Fax (509) 376-4989.

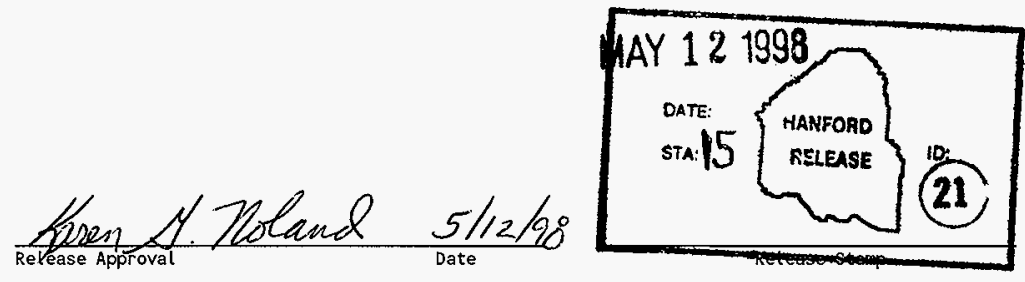

\section{Approved for Public Release}


HNF-1754, Rev 0

\title{
Drill String Gas Data
}

\author{
By \\ Edward R. Siciliano
}

Fluor Daniel Northwest, Inc.

Richland, Washington 


\begin{abstract}
Data and supporting documentation were compiled and analyzed for 26 cases of gas grab samples taken during waste-tank core sampling activities between September 1, 1995 and December 31, 1997. These cases were tested against specific criteria to reduce uncertainties associated with in-tank sampling location and conditions. Of the 26 possible cases, 16 qualified as drill-string grab samples most likely to represent recently released waste gases. The data from these 16 "confirmed" cases were further adjusted to remove non-waste gas contributions from core-sampling activities (argon or nitrogen purge), the atmospheric "background", and laboratory sampler preparation (helium).

The procedure for subtracting atmospheric, laboratory, and argon purge gases was unambiguous. No reliable method for determining the exact amount of nitrogen purge gas was established. Thus, the final set of "Adjusted" drill string gas data for the (6) nitrogen-purged cases had a greater degree of uncertainty than the final results for the (10) argon-purged cases. Including the appropriate amounts of uncertainty, this final set of data was added to the set of high-quality results from the Retained Gas Sampler (RGS), and good agreement was found for the $\mathrm{N}_{2}, \mathrm{H}_{2}$, and $\mathrm{N}_{2} \mathrm{O}$ mole fractions sampled from common tanks. These results indicate that under favorable sampling conditions, Drill-String (DS) grab samples can provide reasonably accurate information about the dominant species of released gas. One conclusion from this set of total gas data is that the distribution of the $\mathrm{H}_{2}$ mole fractions is bimodal in shape, with an upper bound of $78 \%$.
\end{abstract}




\section{ACKNOWLEDGEMENT}

The data use in this report was obtained with the help of many people throughout the Hanford Site. The author would like to express his gratitude to a few special people for their extra help (and patience) in satisfying the author's many requests for data and "other" information associated with this data. In particular, special thanks go to Stan Boss and Milt Goheen at the Pacific Northwest National Laboratory, John Schofield at Lockheed Martin Hanford Company and Kyleen Smith at Fluor Daniel Hanford. Without them, completion of this report would not have been possible. 


\section{CONTENTS}

1.0 BACKGROUND

2.0 OBJECTIVES

3.0 METHODS

3.1 Objective 1 - Data Compilation

3.1.a Procedural Steps:

3.1.b Major Assumptions \& Sources of Uncertainty:

3.2 Objective 2 - Data Value Assessment

3.2.a Procedural Steps:

3.2.b Major Assumptions \& Sources of Uncertainty:

3.3 Objective 3-Data Adjustment

3.3.a Procedural Steps:

3.3.b Major Assumptions \& Sources of Uncertainty:

4.1 Adjusted Mole Fractions

4.2 Distributions

$\begin{array}{llr}5.0 & \text { SUMMARY \& CONCLUSIONS } & 18\end{array}$

$\begin{array}{ll}6.0 \text { REFERENCES } & 19\end{array}$

$\begin{array}{ll}7.0 \text { GLOSSARY } & 20\end{array}$

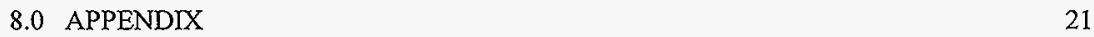

8.1 DS Data Tables $\quad 23$

$\begin{array}{ll}8.2 & \text { Documented Information }\end{array}$

$\begin{array}{ll}8.3 \text { Atmosphere Data } & 30\end{array}$

8.4 Adjusted DS Data Tables 31 


\section{FIGURES}

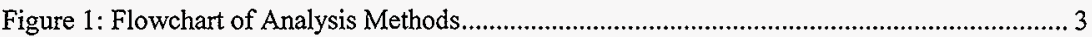

Figure 2: Nitrogen Data from the RGS \& Drill-String Analyses......................................... 14

Figure 3: Hydrogen Data from the RGS \& Drill-String Analyses ................................................. 15

Figure 4: Nitrous Oxide Data from the RGS \& Drill-String Analyses ........................................ 15

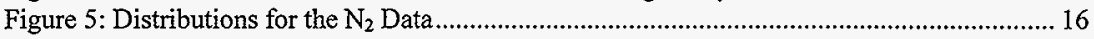

Figure 6: Distributions for the $\mathrm{H}_{2}$ Data

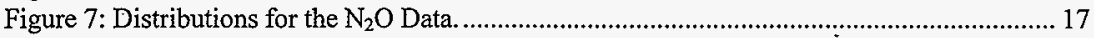




\section{TABLES}

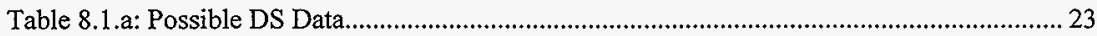

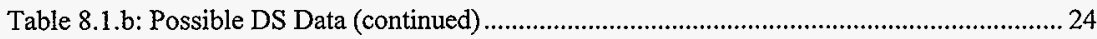

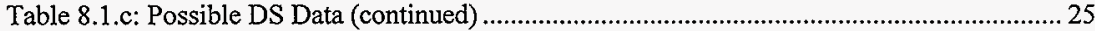

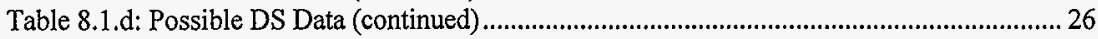

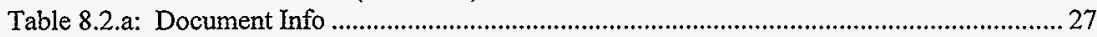

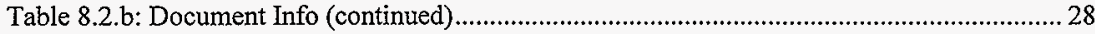

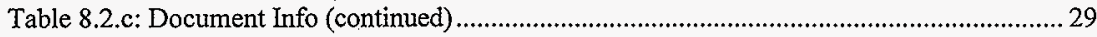

Table 8.3.a: Data Used as "Air Standard" ........................................................................................ 30

Table 8.3.b: Uncertainties in Atmospheric Scaling ........................................................................... 30

Table 8.4.a: Adjusted DS Data for Ar-Purge Cases...................................................................... 31

Table 8.4.b: Adjusted DS Data for Ar-Purge Cases (continued) ................................................... 32

Table 8.4.c: Adjusted DS Data for $\mathrm{N}_{2}$-Purge Cases......................................................................... 33 


\subsection{BACKGROUND}

Accurate data on gases retained within the wastes stored in the underground tanks at the Hanford Site are essential for resolving flammable-gas safety issues associated with those tanks. Only recently have such retained gas data been available through the deployment of the Retained Gas Sampler (RGS). These data are of high quality and are clearly the best available data for determining retained gas composition and concentrations. However, the amount of RGS data is still somewhat small for building statistically representative probability distributions. Thus, it is desirable to supplement the RGS data with additional retained gas data. One potential source of such data are the drill-string gas grab samples that are sometimes taken by Industrial Hygiene \& Safety $(\mathrm{IH} \& \mathrm{~S})$ technicians during core-sampling activities.

The reason gas samples taken from the drill string may be of value derives from the drill string's function during core-sampling activities, i.e. as the guiding passageway through which the core samplers are deployed into the waste. It is constructed from a series of smaller pipe segments, threaded together as each one is driven into the waste by the drill truck, thus forming a continuous pipeline from the waste to the drill truck. As the drill string is inserted into the waste, retained gas can be released and accumulate in the headspace region within the drill string. This headspace region within the drill string is the source of the samples taken by IH\&S technicians.

The primary responsibility of the IH\&S technician during core-sampling activities is to ensure safe working conditions for the personnel. To detect a possibly hazardous flammable gas condition, the IH\&S technician monitors combustible gas concentrations from different locations above and within the tank. These locations include large open regions (tank vents or breather filters, risers or dome space) as well as smaller restricted regions (drill-string, quill rod, and shielded receiver). If unsafe concentrations of monitored gas are observed, the IH\&S technician takes corrective action appropriate to the location and level of concentration. For example, to mitigate a potentially unsafe combustible gas condition, a purge gas $\left(\mathrm{N}_{2}\right.$ or $\mathrm{Ar}$ ) may be injected or "air venting" of the region may provide sufficient dilution.

In addition to corrective actions to mitigate potentially unsafe conditions, the IH\&S technician may also take gas grab samples when the combustible gas concentration exceeds certain levels. These grab samples are sent to the Pacific Northwest National Laboratory (PNNL) Analytic Chemistry Laboratory (ACL) for mass spectrometer analyses. The results of these analyses are recorded in ACL reports and kept on file at the ACL. For grab samples taken from the drill string, the data in the corresponding ACL reports has the potential of providing valuable information about retained gas concentrations. For this potential to be realized, however, possible non-waste gas contributions from IH\&S corrective actions, special sampler preparations, or other existing conditions must be quantified and used to adjust the original results. The purpose of this report is to prescribe methods for selecting and adjusting drill-string gas data so that these data may be combined with the RGS data for retained-gas distribution analyses. 


\subsection{OBJECTIVES}

The three main objectives of the work reported herein are: 1) the compilation, 2) the assessment, and 3) the adjustment of the drill string (DS) gas data obtained from the (ACL's) mass spectrometer analysis reports. Brief descriptions of these objectives are given below.

1) Data Compilation - The first main objective is to identify the mass spectrometry reports associated with DS grab samples and then to compile the data contained in these reports. [The reports referred to here are the ACL's "Gas Species Analysis" reports from the Gas \& Isotope Mass Spectrometry Laboratory. In this document these reports shall be referred to as the "ACL Reports".] The specific result associated with attaining this objective is the production of one comprehensive data set of "Possible" DS gas data.

2) Data Value Assessment - The second main objective is to reduce the above set of Possible DS gas data into a set of "Confirmed" DS data that are most likely to represent retained gas conditions. The need for this assessment arises because obtaining grab samples is an occasional secondary task for the IH\&S technician, and thus there are uncertainties associated with the sampling locations and conditions. The goal of this objective is to establish a set of criteria that assures the sample location and provides guidelines for selecting sets of data that are more likely to represent recently-released retained gas ("Young" gas) data that qualify as retained-gas grab samples according to that set of documented criteria.

3) Data Adjustment - The third main objective consists of two parts: the specification of a simple, but well-founded calculation procedure that would account for non-waste gas components, and the use of this procedure to obtain a set of "Adjusted" DS data that should be more representative of the actual waste-generated gases. The specific result associated with attaining this third main objective is the production of a set of adjusted DS data for supplemental use with the RGS data. These results are shown in frequency and cumulative distributions for both the RGS and Adjusted DS data.

In addition to the uncertainties associated with the location and age of each sample (addressed above in Objective 2), there is also the usual concern about the intrinsic uncertainties ("random errors") associated with all acts of measurement. Any discussion or use of quantitative data is not complete without providing values for these uncertainties in both the original input data and the final calculated results. In this report, discussions about the sources and propagation of these uncertainties will be included at each stage of development. 


\subsection{METHODS}

The purpose of this section is to describe the procedures used to attain the three main objectives of this report. To help show the interrelationships among these procedures and their roles in attaining the objectives, a process flowchart, labeled Figure 1, is given below. In this chart, standard flowchart symbols are used to depict actions (rectangles), decision filters (diamonds), and documents or data lists (the "partial-page" shapes). The analysis process begins at the top and flows downward, with the final product being the "Adjusted" DS Data files, enclosed within the dashed oval.

\section{Figure 1: Flowchart of Analysis Methods}

Ob jective I - Data Com pilation

Use "Report Recipient Name" as keyword search parameter. Compile list of Names (5).

For each "Name", the Analy tic Chemistry Lab (ACL) locates the Mass Spec Reports and supporting documents.

Obtain Sets of Documents from ACL Each set consists of three documents: the ACL (Mass Spec) Report, Analytic Service Request (ASR), and the Chain of Custody (CoC). (Obtained 26 sets from 5 names.)

Ob jective 2 - Data Assessment

For each Report, use doc.s to confirm location of sample.

Define "Young" gas criteria, (N2+O2+Ar)< $99.7 \%$ \& $(H 2)>5.5 \% L F L)$ and test each Report.

Objective 3 - D ata Ad justment

Subtract $02, \mathrm{Ar}$, \& He from data. Use 02 as "air tag gas" to subtract atmos pheric source of N2. then recalculate mole fractions.
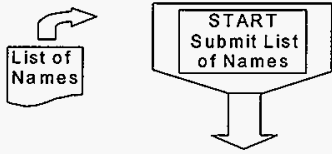

$A C L$ Search for Documents
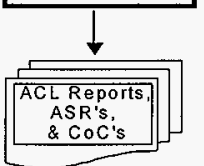

"Possible" DS Data

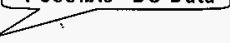

\& $\mathrm{COC}$ 's
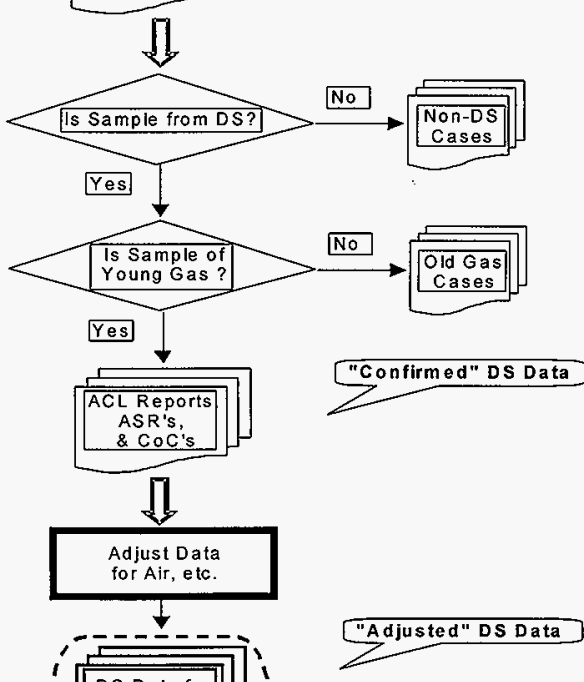
The details of the procedures associated with the main objectives are presented in the same order as depicted in the flowchart. The discussion for each main objective begins with a short description of the goal and the location of the data that resulted from implementing the procedure. Then a detailed description of the procedural steps is given, followed by a list of the major assumptions and possible sources of uncertainty associated with the assumptions. The final results obtained by following these procedures are presented in the Results section.

\subsection{Objective 1 - Data Compilation}

The goal of the first objective was to compile a set of "Possible" DS gas data. These data are in the form of mole fractions, and are listed in Tables 1.a-1.d of the Appendix section.

\section{1.a Procedural Steps:}

The first task in compiling the DS gas data was the identification and collection of all possible ACL Reports that resulted from grab samples submitted by IH\&S. This task was accomplished with assistance from members of the ACL Analytical Chemistry Office (ACO) and the Molecular \& Mass Spectrometry Lab. The ACL Reports are one-page listings that are assigned unique identification numbers, the "ALO Log-in" number, and the reports are kept on file at the ACL. In addition to the ALO number (called the "Log-in No." in the report), the name of the report recipient, analysis date, and sample identification are also recorded on the ACL Reports. The sample analysis results are listed as mole fractions (in percent volume) for thirteen chemical species. (Space for additional comments by the ACL staff is also available on the report, but seldom used.)

Because the ALO numbers of the desired reports were unknown, the names of all the people who may have received DS gas reports were used as keyword search parameters for selecting the candidate ACL Reports. The search was limited to reports submitted from 9/1/95 to 12/31/97 (temporally overlapping with the RGS data). With assistance from personnel at the Characterization Project Office (CPO), Characterization Field Engineering (CFE), and IH\&S; five names were selected. The results of this search produced 26 ACL Reports, and, in some cases, copies of the cover letter addressed to the original recipient.

Once these 26 reports were obtained, the Data Compilation objective was met by entering the results into one comprehensive set of Possible DS gas data. The ALO numbers, analysis dates, and mole fractions that comprise this data set are listed in the top two information blocks of Tables 1.a-1.d of the Appendix. These data are the initial input for the analysis presented in this report.

\section{1.b Major Assumptions \& Sources of Uncertainty:}

The major assumption made in compiling this set of data was the use of (only) five report recipients for the range for the search parameter. The uncertainty associated with this 
assumption is that it was not an exhaustive search that guaranteed identification of all possible reports, i.e. there may be more.

Another possible source of error is incorrect data entry. Because all the original data was entered by hand, it was possible for typographical errors to occur in the observed mole-fraction values. To help eliminate these errors, sums over all mole-fraction data for each sample were checked against the total $(100 \%)$ mole-fraction normalization. This "sum-rule" check was used at each stage of analysis to help locate other possible sources of errors in the data manipulations.

It is also important to mention that the instrumental precision of the mole-fraction values listed in the reports were very high (i.e., statistical uncertainties less than $2 \%$ for most species, with notable exception for $\mathrm{NH}_{3}$ ). Thus these data alone are considered of high quality. However, the information in these reports alone does not establish the sample origin or sampling conditions. Without additional corroborating information, these high-quality data may be of little value as pertaining to retained gas. This issue of data value is addressed in the second objective.

\subsection{Objective 2 - Data Value Assessment}

The goal of the second objective is to select from the total set of Possible DS data a subset of data that qualify both as DS grab samples and as most likely representative of recently-released retained gas. This objective is attained by subjecting each member of the total set to two separate decision filters. The first filter tests for sample location, and is used to assure that the sample location was the DS. The second filter tests for sampling conditions, and is used to select samples taken close in time to a detected increase in combustible gas ("Young" gas). Note that these two decision filters are represented in the flowchart by the two diamond shapes.

The implementation of these decision filters requires definitions of binary (Yes/No) decision criteria. These criteria (choice of decision parameters and their threshold values) were established by means of information from additional supporting documents and interviews with critical personnel when necessary. In the paragraphs below, the procedures used to identify, compile, and assess this additional information are discussed first (subsection 3.2.a.1). The specific decision criteria resulting from this assessment are presented next (subsection 3.2.a.2). The status of the supporting documentation search and associated supporting information is summarized in Tables $2 . a-2$.c. The values for some of the decision parameters for each member of the Possible DS data set are listed in the bottom half of Tables 1.a-1.d.

\section{2.a Procedural Steps:}

\section{2.a.1 Supporting Documents}

In addition to the ACL Report, the following three primary supporting documents were identified as sources of corroborative information: 1) the ACL's Analytic Services Request (ASR) form, 2) the IH\&S's "Attachment A - Chain of Custody and Laboratory Request" (CoC) sheet ${ }^{1}$, and 3) the IH\&S's "Direct Reading Instrument (DRI) Survey" sheet. Copies of these additional documents for the 26 Possible DS cases were obtained from the ACL and IH\&S records. Searches of the

1) The CoC sheet is page 8 from the "IH\&S Operating Procedure, Stainless Steel, Gas Collection Cylinder." 
ACL records produced $26 \mathrm{ASR}$ forms and $25 \mathrm{CoC}$ sheets. Searches into the IH\&S records and special requests made to the individual IH\&S surveyors produced 21 DRI sheets of the 26 cases sought.

For the most part, the information from these documents provided enough evidence to establish the sampling locations and conditions. For the cases where these documents did not provide sufficient information, additional information was obtained from the Characterization Field Engineering Log \& Procedure Data Sheets (CFE Log's) and interviews with relevant personnel.

The linkage among the ACL Reports and the additional supporting documents begins with the ALO number. When a grab sample arrives at the ACL for analysis, an ASR form is completed and an ALO number is assigned (by the "Analytic Laboratory Office") to the task. The ACL staff member who takes possession of the sample also signs the $\mathrm{CoC}$ sheet, and a copy of this sheet is kept in the ACL files. From these two documents, the following information is potentially available:
a. Names of people who obtained (IH\&S surveyor), shipped, and received (ACL staff) the sample
b. The IH\&S survey number (referred to as the DRI number)
c. Dates \& times sampled, shipped, and received
d. Name of ACL Report recipient
e. Example identification number and description
f. Additional comments

Thus, starting with a particular ALO number, it is possible to trace the sample back to the DRI number and the surveyor who obtained the sample. Note that not all this information is required, and unless the tank and DS are included in items $\mathrm{E}$ or F, the ASR and $\mathrm{CoC}$ documents will not establish a definite source for the sample. In that case, obtaining the information from the actual surveyor's $\log$ (entered in the DRI sheet) becomes essential. The compilation status and relevant information obtained from the three additional supporting documents (and the CFE Logs or interviews when needed) is summarized in Tables 2.a-2.c for each case, listed by ALO number.

\section{2.a.2 Decision Criteria}

\section{2.a.2.1 Sample Location Filter}

To assure that the location of a gas sample was the DS, it was deemed necessary to establish the tank name, sampling date and time, surveyor's name, and some indication that the DS was the source of surveyor's grab sample. Acceptable values for these parameters had to be obtained from written documentation. This method leaves no doubt that a consistent path from the ALO number to the DS can be established as the sample source.

Subjected to these criteria, 21 of the 26 cases qualified as DS grab samples, 1 was taken from the quill rod, and 4 were for grab samples from a waste tank vault (244-AR). Additional information about the sampling conditions for the quill-rod case resulted in it also qualifying as an "equivalent" DS sample; thus giving 22 as the total number of qualified DS cases. 


\section{2.a.2.2 Sampling Condition Filter}

The purpose of this filter was to select from the above set of qualified DS cases, those that were most likely to represent recently released gas. There were four decision parameters chosen for this purpose: the sum $\mathrm{N}_{2}+\mathrm{O}_{2}+\mathrm{Ar}$, the ratios $\mathrm{N}_{2} / \mathrm{O}_{2}$ and $\mathrm{Ar} / \mathrm{O}_{2}$, and the percent lower flammability limit (LFL) of $\mathrm{H}_{2}$ in air (where $100 \% \mathrm{LFL}$ is equivalent to a $0.04 \mathrm{H}_{2}$ mole fraction). These parameters were calculated from the observed mole fraction data and their values are listed in the bottom half of Tables 1.a-1.d under the title "Useful Combinations."

The threshold values for distinguishing "Young" from "Old" samples were taken from the 4 nonDS cases (ALO Numbers 96-03499 through 96-03502, listed in Table 1.b). Although this choice of values is somewhat subjective, they do show a behavior that is considered characteristic of an older gas release, i.e. mostly air with a residual amount of $\mathrm{H}_{2}$. Specifically, a sample was rejected if both of these conditions were true:

1) The sum of $\mathrm{N}_{2}+\mathrm{O}_{2}+\mathrm{Ar}$ was greater than or equal to $99.7 \%$ and either one of the ratios $\mathrm{N}_{2} / \mathrm{O}_{2}$ or $\mathrm{Ar} / \mathrm{O}_{2}$ was close to the standard atmosphere values (listed in Table 3.a); and

2) $\mathrm{The}_{2}$ concentration was less than or equal to $5.5 \%$ of the LFL for $\mathrm{H}_{2}$ in air (i.e. an observed $\mathrm{H}_{2}$ mole fraction of 0.22 ).

Subjected to these criteria, 6 out of the 22 cases that passed the location filter failed, resulting in a total of 16 cases in the set of Confirmed DS Data. These cases are the set of data that were further adjusted to remove the non-waste contributions, as discussed next.

\section{2.b Major Assumptions \& Sources of Uncertainty:}

The main assumptions for determining the decision criteria were to:

1) Require that either written documentation and/or enough other supporting information was needed to establish a consistent path from the ALO number to the DS as the sample source, and to

2) Use the four cases of definite non-DS locations to establish the "Young" gas criteria.

Both of these assumptions are considered conservative, in the sense that they eliminate data from questionable locations and that using the above 5.5\%LFL of $\mathrm{H}_{2}$ in air as a cutoff tends to weight the acceptable cases towards the higher $\mathrm{H}_{2}$ concentrations.

\subsection{Objective 3 - Data Adjustment}

The goal of the third objective was to establish and apply calculation procedures for adjusting the observed mole-fraction data to account for the non-waste gas contributions. The presentation of these procedures is given in two parts. First, a short discussion is given about each source of non-waste gases and the prescriptions adopted to obtain their amounts. Then, the specific equations used to implement these prescriptions are presented. The final numerical results obtained by evaluating these equations are listed in Tables $4 . a-4 . c$ of the Appendix. (Values of some intermediate calculations are also given in these tables.) These results comprise the final "Adjusted" DS data goal of this report. 


\section{3.a Procedural Steps:}

\section{3.a.1 Non-Waste Sources and Calculation Prescriptions}

Three sources of non-waste gases are considered in this report: the ambient atmosphere (air), purge gases used during core-drilling operations, and laboratory gases used for special sampler preparations. The air and purge-gas contributions dominate the non-waste sources because the sampling procedures followed by the IH\&S technician allows for variable amounts of air and purge gas to be entrained into the DS grab sample. However, small amounts of non-waste gas from pre-sampling laboratory activities were detected. In particular, all detectable amounts of $\mathrm{He}$ were assumed to result from the special RGS helium "back-fill" procedure used to prepare some of those samplers. The procedures for determining the compositions and amounts from the air and purge gases are specified separately below.

\section{3.a.1.1 Air}

The composition of the ambient atmosphere is taken from the standard reference (Lide 1994)) used to represent an idealized composition for dry air at standard temperature and pressure (STP conditions). From this reference, the four largest components are $\mathrm{N}_{2}, \mathrm{O}_{2}, \mathrm{Ar}$, and $\mathrm{CO}_{2}$, where the contributions from $\mathrm{N}_{2}, \mathrm{O}_{2}$, and Ar comprise $99.96 \%$ of the total standard volume. The percent volume concentrations of these four components and ratios calculated from those values are listed in Table 3.a of the Appendix.

To determine the amounts of these species that result from air, $\mathrm{O}_{2}$ was assumed to be an atmospheric indicator or "tag" gas, whose observed value is unaltered by the waste environment over the time scale of interest.". amounts of $\mathrm{N}_{2}, \mathrm{Ar}$, and $\mathrm{CO}_{2}$ to be calculated by multiplying the observed value of $\mathrm{O}_{2}$ times the appropriate scaling factors (ratios listed in Table 3.a). The final procedure, therefore, was to identify the observed amount of $\mathrm{O}_{2}$, and the appropriately scaled amounts of $\mathrm{N}_{2}, \mathrm{Ar}$, and $\mathrm{CO}_{2}$ as the total contribution of non-waste gases resulting from entrained air.

\section{3.a.1.2 Purge Gases}

The type of purge gas associated with each DS case depended upon which core drill truck was used for sampling. The specific truck used for each sampling case was determined from the CFE Log files, where the daily activities of each drill truck are recorded. Using the documented tank. names and sampling dates, the information in the CFE Log files was sufficient to establish the specific core drill trucks (and thus the specific purge gas) for each DS data set. These results are listed in the bottom half of Tables 1.a-1.d. Of the 16 Confirmed DS cases, these results show that 10 were Ar purged and 6 were $\mathrm{N}_{2}$ purged.

1) From various studies on actual waste-gas generation rates, free oxygen (not $\mathrm{O}_{2}$ ) appears to be liberated through radiolysis and then rapidly scavenged by the waste. See Shekkariz et al. (1997) for further discussion on use of $\mathrm{O}_{2}$ as an atmospheric tag gas for grab samples. 
As for the amounts of Ar or $\mathrm{N}_{2}$ purge gas, no reliable method was found. This lack of quantification method is of no consequence for the Ar-purged cases, because the only other source of $\mathrm{Ar}$ is the atmosphere (i.e. the waste does not produce it). Thus, the observed amount of $\mathrm{Ar}$ is the total non-waste amount. However, $\mathrm{N}_{2}$ is produced by the waste, and the inability to determine the amount from $\mathrm{N}_{2}$ purging results in large uncertainties for those cases.

\section{3.a.1.3 Summary of Prescriptions for Non-Waste Evaluations}

For all the 16 Confirmed DS cases, the total observed mole fractions for $\mathrm{O}_{2}, \mathrm{Ar}$, and $\mathrm{He}$ are considered unambiguous non-waste contributions. For the 10 Ar-purged cases, the only source of non-waste $\mathrm{N}_{2}$ is the atmosphere, and thus the total non-waste amount of $\mathrm{N}_{2}$ is determined by the $\mathrm{O}_{2}$ atmospheric scaling method. For the $6 \mathrm{~N}_{2}$-purged cases, the amount of non-waste $\mathrm{N}_{2}$ from the atmosphere is also determined by $\mathrm{O}_{2}$ scaling, but the amount of non-waste $\mathrm{N}_{2}$ from purging is undetermined. The specific calculations used to implement these procedures are given next.

\section{3.a.2 Calculation of Adjusted Mole Fractions}

The numerical results for the final Adjusted DS mole fractions are obtained by evaluating the expression:

Eq. 1, $\quad f_{i}^{D S}=\left(f_{i}^{O}-g_{i}^{N W}\right) / C$, where $C=1-\sum_{i=1}^{13} g_{i}^{N W}$.

In this equation, $f_{i}^{D S}$, represents the desired output, $f_{i}^{O}$ represents the observed (O) mole fraction input, and $g_{i}^{N W}$ represents the non-waste $(\mathrm{NW})$ portion of $f_{i}{ }^{O}$ as specified in the above paragraph. The subscript index $(i=1-13)$ corresponds to the 13 chemical species of observed mole fractions listed in Tables 1.a-1.d. The factor, $C$, is required to obtain properly normalized results because the input mole fraction data are normalized, i.e. $\sum_{i=1}^{13} f_{i}^{o}=1$, and a reduction to any one of those values requires a redistribution of all the fractional amounts.

To complete the definition of Eq. 1 , specific expressions for the NW input parameters $\left(g_{i}^{N W}\right)$ are constructed in accordance with the prescriptions given in the preceding section. From that discussion, only $4\left(\mathrm{O}_{2}, \mathrm{Ar}, \mathrm{He}\right.$, and $\left.\mathrm{N}_{2}\right)$ of the 13 observed mole fractions are influenced by NW sources. Moreover, the amounts for 3 of these are assumed to be unaltered by the waste environment, implying the NW parameters for these species are the observed mole fractions. These specifications are summarized in the following expression:

Eq. 2, $g_{i}^{N W}=\left\{\begin{array}{l}f_{i}^{O}, \text { for } \mathrm{O} 2, \mathrm{Ar}, \text { and } \mathrm{He} \\ g_{N 2}^{A}+g_{N 2}^{P}, \quad \text { for } \mathrm{N} 2 \\ 0, \quad \text { for all other species }\end{array}\right.$,

where $g_{N 2}^{A}$ and $g_{N 2}^{P}$ are the (yet to be specified) amounts of $\mathrm{N}_{2}$ from the atmosphere (A) and $\mathrm{N}_{2}$ purge $(\mathrm{P})$ sources. Before specifying these $\mathrm{N}_{2}$ parameters, the following symbol is defined for the sum of the 3 unaltered (UA) non-waste amounts, 
Eq. 3, $\quad G^{U A} \equiv \sum_{O 2, A r, H e} g_{i}^{N W}=f_{O 2}^{O}+f_{A r}^{O}+f_{H e}^{O}$.

As indicated in Eq.2, the non-waste amounts of $\mathrm{N}_{2}$ are evaluated differently from the other nonwaste gases. This difference arises because the waste produces $\mathrm{N}_{2}$, and proper deduction of that amount requires evaluation of the contributions from the non-waste sources explicitly. The atmospheric contribution is determined from the $\mathrm{N}_{2}$-to- $\mathrm{O}_{2}$ scaling ratio in Table 3.a, i.e.

Eq. 4,

$$
g_{N 2}^{A}=R_{N 2: O 2} f_{O 2}^{O}, \text { where } \underset{N 2: 02}{R}=3.73 .
$$

For the (10) Ar-purged cases, the parameter $g_{N 2}^{P}=0$ in Eq.2, and the procedure for determining $g_{N 2}^{A}$ given in Eq.4 completes the specification of the input required to evaluate Eq.1. The final results for these cases are given in Tables 4.a and 4.b. For the (6) $\mathrm{N}_{2}$-purged cases, the parameter $g_{N 2}^{P} \neq 0$, and an additional procedure is required to specify this parameter for those cases. Before presenting this additional procedure, a step-by-step evaluation for one of the Ar-purged cases is given as an example application of the above procedures.

\section{3.a.2.1 Example Ar-Purged Calculation}

The case chosen for this example is ALO Report number 95-09000, which was analyzed on $9 / 27 / 95$, and was obtained from tank S-107, riser R-2, on $9 / 27 / 95$. This case reference data is listed in the top information block of the final output tables $(4 . a-4 . c)$. Note that the data listed below each case in these tables are grouped into two additional blocks of information. The middle block contains numerical results from evaluation of the intermediate steps (Eqs. 2,3,etc.); and the lower block contains the final numerical results from using those intermediate values to evaluate Eq.1. (Further note that all the concentration data in these tables are given as percent mole fractions.)

The starting input for this particular case - the observed mole fractions for ALO No. 95-09000 is listed in the top two information blocks of Table 1.a. (Note the ALO Report number is the primary identification parameter that links the observed mole fractions listed in Tables 1.a-1.d to the final Adjusted DS mole fractions in Tables 4.a-4.c.) The first step is to use the observed percent mole fractions given in that table for $\mathrm{O}_{2}, \mathrm{Ar}$, and $\mathrm{He}(20.2 \%, 0.94 \%$, and $0 \%$ ) to evaluate Eq. 3 for the sum of unaltered non-waste amounts $(21.14 \%)$. This result is listed in Table 4.a, on the line labeled "G."

The next step is to use the observed value of $\mathrm{O}_{2}(20.2 \%)$ to evaluate Eq.4 for the atmospheric amount of $\mathrm{N}_{2}(75.3 \%)$, which is listed on the line labeled " $\mathrm{N}_{2}$ from $\mathrm{O}_{2}$." The non-atmospheric amount is defined as the difference between the observed amount of $\mathrm{N}_{2}(78 \%)$ and the atmospheric amount, i.e. $\left(f_{N 2}^{O}-g_{N 2}^{A}\right)$, and is given (as 2.71\%) on the line labeled "NAtm. $N_{2}$." (In a similar manner, analogous values for the expected amounts of atmospheric Ar are also calculated and listed in the tables.

The last line of intermediate results, labeled "NCF," uses the mole fraction values of $\mathrm{G}$ and $\mathrm{N}_{2}$ from $\mathrm{O}_{2}$ to obtain the normalization correction factor (C) defined in Eq.1. The numerical result is $0.0357(=1-0.2114-0.753)$. This result completes the set of input parameters used to evaluate Eq. 1 and to obtain the set of final Adjusted percent mole fractions listed in the bottom 
information block of Table 4.a. Note that the Adjusted $\mathrm{N}_{2}$ value is calculated by dividing the non-atmospheric $\mathrm{N}_{2}$ ("NAtm. $\mathrm{N}_{2}$ ") by $\mathrm{NCF}$, whereas the other final values are just the observed mole fractions divided by NCF. This completes the discussion for the Ar-purged cases.

For the (6) $\mathrm{N}_{2}$-purged cases, an additional procedure is required to evaluate the non-waste input parameter, $g_{N 2}^{P}$, called for in Eq.2. This parameter represents the amount of $\mathrm{N}_{2}$ purge gas entrained into the sample; however, no reliable method was found for determining the exact amount of this type of purge gas. Thus, in the absence of any additional information, the only justified procedure is to take $g_{N 2}^{P}$ as equally likely to have any value over the full range of possible values. This range of possible values is determined from the amount of nonatmospheric $\mathrm{N}_{2}$, i.e.

Eq. 5, $\quad g_{N 2}^{P}=\alpha\left(f_{N 2}^{O}-g_{N 2}^{A}\right)$, where $0 \leq \alpha \leq 1$.

Using the full range of possible $g_{N 2}^{P}$ values (in Eqs.2 and 1) for calculating the final Adjusted DS mole fractions would give values for $f_{N 2}^{D S}$ ranging from a maximum value, $f_{N 2}^{M a x}$ (for $\alpha=0$ ), to a minimum value of zero (for $\alpha=1$ ). Given that a zero value for waste-released $\mathrm{N}_{2}$ has never been observed, setting $\alpha=1$ was deemed highly unlikely. Instead, the minimum value of the $\mathrm{N}_{2}$ Adjusted mole fractions obtained from the (10) Ar-purged cases $\left(f_{N 2}^{\mathrm{Min}}=0.236\right)$ was used to set the maximum purge parameter, $\alpha^{\text {Max }}$.

To characterize this range of values for $g_{N 2}^{P}$, an average purge parameter, $\alpha^{A v g}$, was also determined by fixing a final Adjusted $\mathrm{N}_{2}$ midpoint value to be the average over the two extreme values, i.e. $f_{N 2}^{A v g}=0.5\left(f_{N 2}^{\mathrm{Aax}}+0.236\right)$. The final procedure was to use these two fixed values to define the range of final $\mathrm{N}_{2}$ results, calculate the associated purge parameters, and then use those parameters to calculate the final mole fractions for the other species. The general expression used to calculate the purge parameters is obtained by inverting Eq.1 to solve for $\alpha$ given a value of $f_{N 2}^{D S}$, i.e.

Eq. 6,

$$
\alpha=\left[1-f_{N 2}^{D S}\left(1-G^{U A}-g_{N 2}^{A}\right) /\left(f_{N 2}^{O}-g_{N 2}^{A}\right)\right] /\left[\left(1-f_{N 2}^{D S}\right)\right] .
$$

Equations 5 and 6 complete the definitions of the additional procedure required to evaluate Eqs. 1- 4 for the $\mathrm{N}_{2}$-purged cases. The final results for these cases are listed in Table 4.c. To demonstrate the application of this additional procedure, a step-by-step evaluation of one of the $\mathrm{N}_{2}$-purged cases listed in that table is given next.

Before giving an example $\mathrm{N}_{2}$-purged calculation, it is worth noting that the two numbers used in all the tables for reporting the final results represent the best estimate and the range of total estimated uncertainty. Note that these two numbers are not the usual mean and standard deviation associated with a "Normal" distribution. Because this range is determined from the systematic uncertainties (and not the usual random uncertainties associated with repeated measurements and instrument precision), the best estimate is the midpoint over a range of equal probability, i.e. a flat distribution. For the Ar-purged calculations, the range of systematic uncertainty was taken to be $10 \%$, and the best estimate value was taken to be the value obtained without averaging. For the $\mathrm{N}_{2}$-purged cases, the range of values was determined from the range of uncertainty in the amount of $\mathrm{N}_{2}$ from the purge. 


\section{3.a.2.2 Example $\mathrm{N}_{2}$-Purged Calculation}

The case chosen for this example is ALO Report number 96-00695, which was analyzed on $10 / 26 / 95$, and was obtained from tank BY-110, on 10/24/95. This case is the first one listed in Table 4.c. As with the previous argon example, the starting input is listed (under the second case) in Table 1.a, and the parameters $G^{U A}, g_{N 2}^{A}$, and $C$ (associated with Eqs. 3, 2, and 1) are determined from the observed percent mole fractions for $\mathrm{O}_{2}, \mathrm{Ar}$, and $\mathrm{He}$. For this case, these values are $1.17 \%, 0.125 \%$, and $0 \%$, respectively; and they give the sum of unaltered non-waste amounts $G^{U A}=1.295 \%$. This result is listed in Table 4.c, on the line labeled " $\mathrm{G}$." The observed value of $\mathrm{O}_{2}$ is also used in Eq.4 to evaluate the atmospheric amount of $\mathrm{N}_{2}(4.36 \%)$, which is listed on the line labeled " $\mathrm{N}_{2}$ from $\mathrm{O}_{2}$ ".

Unlike the Ar-purged cases, a second estimate of the atmospheric amount of $\mathrm{N}_{2}$ is made by using the N2-to-Ar scaling ratio (83.96) from Table 3.a and the observed amount of Ar. This result $(10.5 \%)$ is listed in Table 4.c on the line labeled "N2 from Ar." The final value used for the $g_{N 2}^{A}$ parameter is the average $(7.41 \%)$ from both these scaling calculations (listed in the table as "Av.Atm. $\mathrm{N}_{2}$ "). This value is subtracted from the observed amount of N2 (57.1\%) to obtain the non-atmospheric amount of $\mathrm{N} 2$, i.e. $\left(f_{N 2}^{O}-g_{N 2}^{A}\right)$, and is given (as 49.7\%) on the line labeled "NAtm. $\mathrm{N}_{2}$."

As in the Ar-purged case, the normalization correction factor, $\mathrm{C}$ (Eq.1) is evaluated for no purge $\mathrm{N}_{2}\left(g_{N 2}^{P}=0\right)$ by using the mole fraction values of " $\mathrm{G}$ " and "Av.Atm. $\mathrm{N}_{2}$." The numerical result $(0.913=1-0.01295-0.0741)$ is listed as "NCF" in the table. Note this value represents the situation for maximum waste $\mathrm{N}_{2}$, corresponding to the purge parameter $\alpha=0$ in Eq.5, i.e. $f_{N 2}^{\mathrm{Max}}=\mathrm{NAtm} . \mathrm{N} 2 / \mathrm{NCF}(54.4 \%)$. These values for NCF and $f_{N 2}^{\mathrm{Max}}$ are used to determine the upper limits for the ranges of all the final Adjusted DS species.

To complete the $\mathrm{N}_{2}$-purged evaluation procedure, the midpoint values of the final Adjusted mole fractions are calculated. This is accomplished by using the above value of $f_{N 2}^{\mathrm{Max}}$ to calculate $f_{N 2}^{A v g}=0.5\left(f_{N 2}^{M a x}+0.236\right)$, and then by using this value of $f_{N 2}^{A v g}$ in Eq. 6 to obtain $\alpha^{A v g}$. The values for $f_{N 2}^{A v g}$ and $\alpha^{A v g}$ are given in Table 4.c on the lines labeled "Av.X." (as 39.0\%) and "Av.Alpha" (as 0.464), respectively. Using this value for the average purge parameter, an average amount of purge gas is determined from Eq.5 and used to calculate a "Purge-Adjusted" normalization correction factor, listed on the line labeled "PANCF" (as 0.682).

The values for PANCF and $f_{N 2}^{A v g}$ are used to determine the midpoints for the ranges of all the final Adjusted DS species listed in the "best estimate" column of Table 4.c. Note that the upper limit values for the mole fraction ranges are obtained from the data listed in Table 4.c by adding the midpoint values to the "error" column values. (For example, the upper limit for $f_{N 2}^{D S}$ is the sum of $39.0 \%$ and $15.4 \%$.) These midpoint values listed in the bottom information block of Table 4.c complete the analysis for the $\mathrm{N}_{2}$-Purged cases.

In summary, the numerical evaluation procedures depend upon the type of purge gas used to obtain the sample. For the (10) Ar-purged cases, Eqs.1 - 4 are used to obtain the final Adjusted DS data. These results are listed in Tables 4.a and 4.b. For the (6) $\mathrm{N}_{2}$-purged cases, Eqs.5 and 6 
are needed to estimate the additional non-waste $\mathrm{N} 2$ contributions from purging activities. The $\mathrm{N}_{2}$-purged results are listed in Table 4.c. Because estimates of the systematic uncertainties associated with the DS data overwhelm all statistical uncertainties, the best estimate and error values listed in these tables describe the midpoint over a range of equal probability, i.e. a flat distribution.

\section{3.b Major Assumptions \& Sources of Uncertainty:}

The major assumptions adopted in this analysis were:

(1) The sources and type of non-waste gas,

(2) The use of $\mathrm{O}_{2}$ as an atmospheric tag gas (i.e. its amount is unaltered by the waste environment), and

(3) The use of an idealized atmospheric composition to determine the scaling ratios used to omit atmospheric gases from the observed data.

Of these issues, the uncertainties in atmospheric composition and scaling ratios listed in Table 3.a were considered to play the most crucial role in this report, and were further explored. In this investigation, three possible sources of uncertainty in these idealized values were identified: calibration of the Mass Spectrometer, deviation from an ideal gas, and impurities from the purge gas canisters. Some data relevant to these issues are listed in Table 3.b.

At the top of this table, values for the mean and standard deviations were calculated from 8 data sets of Mass Spec "Air Standard" data taken from January 6, 1997 through August 11, 1997. These Air Standard tests are performed each week at the Mass Spec Lab as part of their Quality Assurance procedure. Note that the ratios calculated from these data are consistent to three significant figures) with the reference values listed in Table 3.a.

Also in Table 3.b, the measured volumes per mole at STP are listed for the dominant components. These values are worth noting because the reported mole fractions are in percent volume, and it is assumed that all the gases behave as ideal gases in the sense that the molar volume for any species is $22.41 \mathrm{~L} /$ mole. From Table $3 . b$ it is seen that this is a very good approximation, with Ar deviating the most from the others, with a $1.43 \%$ error.

Finally in Table 3.b are listed the critical temperatures for the dominant components, showing that there may be some argon gas in the $\mathrm{N}_{2}$ purge gas (depending upon the quality of fractional distillation). Mass spec tests of various commercially supplied $\mathrm{N}_{2}$ gas showed at most a $0.5 \% \mathrm{Ar}$ contamination. 


\subsection{RESULTS}

In this section, the final Adjusted Drill-String gas data for $\mathrm{N}_{2}, \mathrm{H}_{2}$, and $\mathrm{N}_{2} \mathrm{O}$ that resulted from completing Objective 3 are displayed graphically in Figures 2 through 7 . The numeric values of the data shown in these figures are given the Appendix, Tables 4.a - 4.c. The results from the intermediate steps (used to attain Objectives 1 \& 2) are also tabulated in the Appendix. Note that the three gas species discussed in this section are the dominant species (in descending order) remaining after the non-waste gases are eliminated from the data. The fourth largest species is $\mathrm{CH}_{4}$, which has values that are at least one order-of-magnitude smaller than the smallest value of $\mathrm{N}_{2} \mathrm{O}$. (Those values are also listed in the above tables.)

\subsection{Adjusted Mole Fractions}

Figures 2,3, and 4 show mole fractions as a function of an arbitrary, but unique sample number used to distinguish among the different cases. The data in these figures are from previous analyses of RGS measurements and the current analysis of the drill-string samples. Thus, the set of data shown here is the total set of data currently qualified as either retained or recently released waste gas. In these figures, the RGS data ( taken from Shekkariz 1997 and Mahoney 1997) are displayed as small solid diamonds, and the DS data as larger, hollow diamonds for the argon-purged cases and squares for the nitrogen-purged cases. The tank names from which the samples were taken are also given, and connecting lines are used to indicate data sampled from the same tank. Finally, for the cases where the uncertainty in value exceeds the size of the symbol, the range of that uncertainty is indicated with the vertical error bars.

Figure 2: Nitrogen Data from the RGS \& Drill-String Analyses

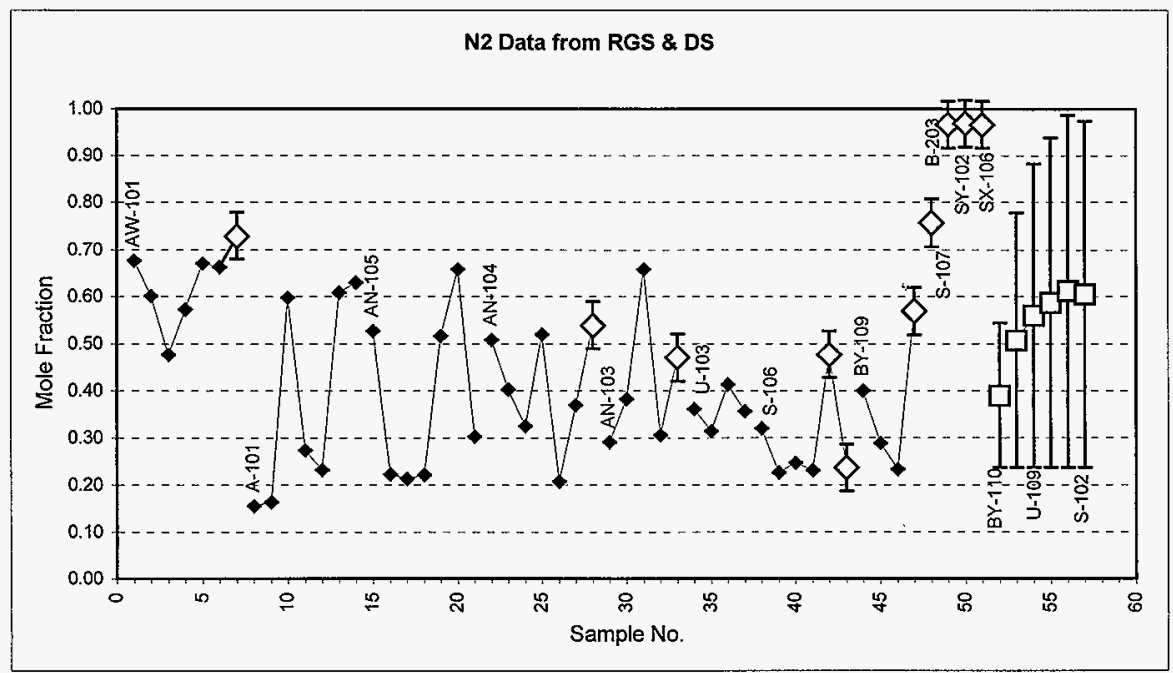


HNF-1754 Rev.0

Figure 3: Hydrogen Data from the RGS \& Drill-String Analyses

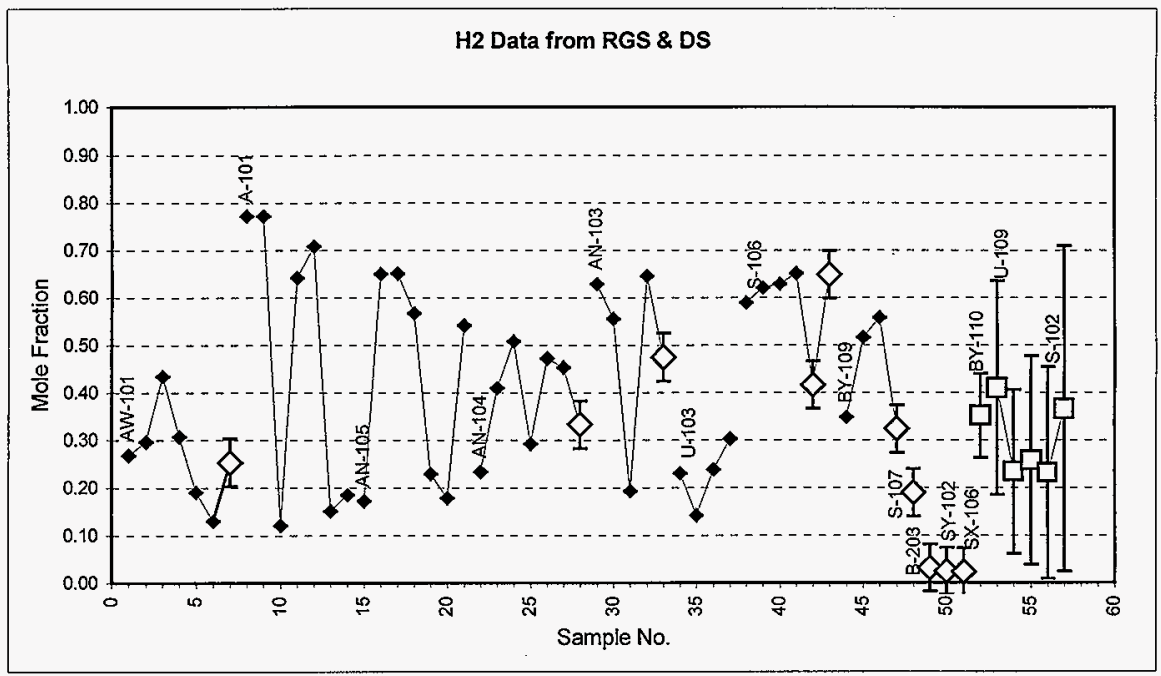

Figure 4: Nitrous Oxide Data from the RGS \& Drill-String Analyses

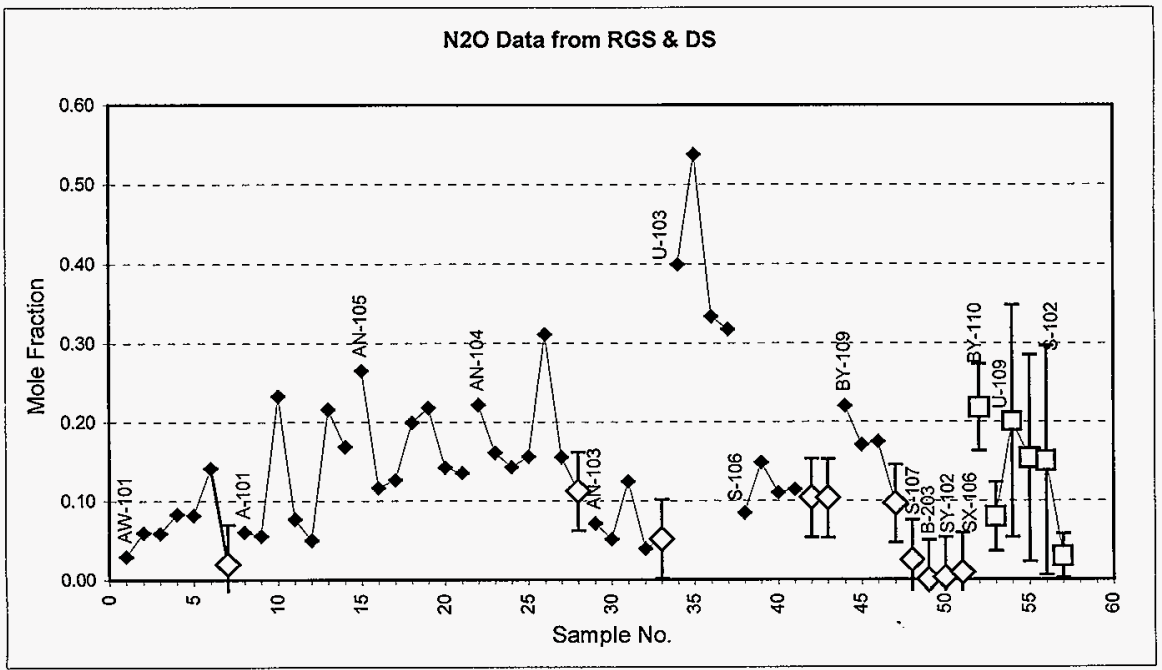




\subsection{Distributions}

From Figures $2-4$ it is observed that the mole-fraction data cover a wide range of values. To show how these data are distributed among the different values, histograms and cumulative percents of the above mole fraction data are given in Figures 5,6, and 7. In these figures, the number of data values (counts) that occur within a given interval (bin) are plotted as vertical bars. The horizontal axis shows the possible range of mole fractions $(0.00-1.00)$ and the numbers of counts for bins of 0.05 are given along the left vertical axis. Three different gray tones used to distinguish among the three different sets of data: the RGS counts are shown as white, the argonpurged DS counts are indicated with light gray, and the nitrogen-purged DS counts with dark gray. The right vertical axis is used for the cumulative percentages of each bin value shown as solid and hollow diamonds connected by solid and dashed lines. The solid diamonds are for the total RGS and DS counts, whereas the hollow diamonds show the cumulative percentage for the RGS counts only.

A crucial element in producing meaningful histograms is the choice of bin width, particularly for the wide variation in the data quality (error bands) shown in Figures $2-4$. The choice of $(0.05)$ bin width was based upon the quality and dominant amount (41 out of 57 values) of RGS data. To account for the large degree of systematic uncertainty associated with the DS data, a "fractional counting" procedure was adopted. This procedure assigned a fractional count from a DS sample if its total range contained the 0.05 bin under consideration. The fractional value assigned to this count was determined by integer division of 0.05 by the total DS range of uncertainty. In this manner, the total number of counts is maintained and data with large amounts of uncertainty can be included with data of higher quality.

Figure 5: Distributions for the $\mathrm{N}_{2}$ Data

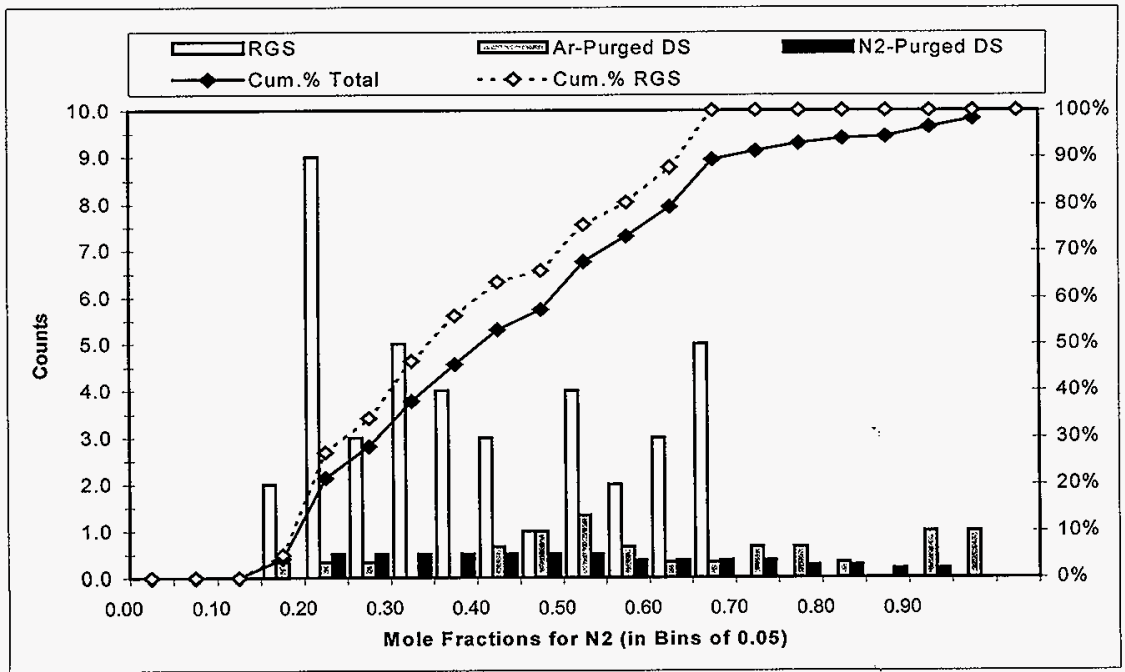


Figure 6: Distributions for the $\mathrm{H}_{2}$ Data

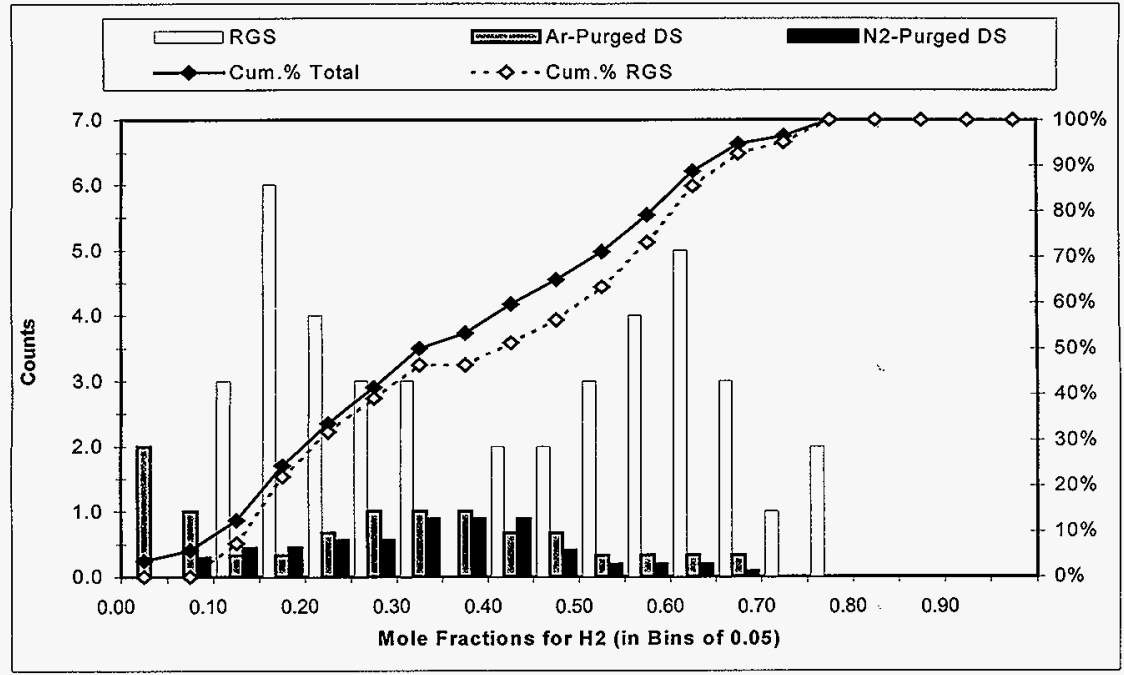

Figure 7: Distributions for the $\mathrm{N}_{2} \mathrm{O}$ Data.

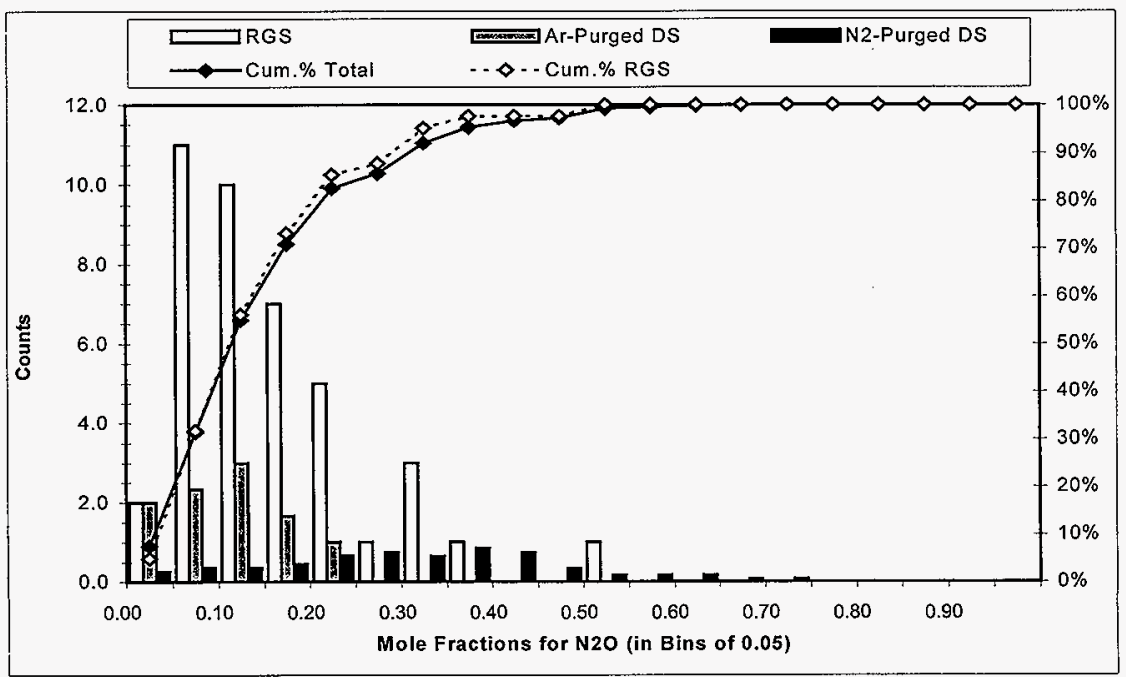




\subsection{SUMMARY \& CONCLUSIONS}

The work reported in this document covered the compilation and analyses of drill-string gas grab samples taken during waste-tank core sampling activities between September 1, 1995 and December 31, 1997. Data and supporting documentation for 26 possible cases were obtained. These cases were tested against specific criteria to reduce uncertainties associated with in-tank sampling location and conditions. Of the 26 possible cases, 16 qualified as drill-string grab samples most likely to represent recently released waste gases. The data from these 16 "Confirmed" cases were further adjusted to remove non-waste argon or nitrogen purge gas contributions from core-sampling activities; nitrogen, oxygen, and argon from the atmospheric "background"; and helium from laboratory sampler preparation.

The procedure for subtracting atmospheric, laboratory, and argon purge gases was unambiguous. No reliable method for determining the exact amount of nitrogen purge gas was established. Thus, the final set of "Adjusted" drill string gas data for the (6) nitrogen-purged cases had a greater degree of uncertainty than the final results for the (10) argon-purged cases. Including the appropriate amounts of uncertainty, this final set of data was added to the set of high-quality results from the Retained Gas Sampler (RGS), and good agreement was found for the $\mathrm{N}_{2}, \mathrm{H}_{2}$, and $\mathrm{N}_{2} \mathrm{O}$ mole fractions sampled from common tanks.

One immediate observation from this set of total gas data is that the frequency distribution of the $\mathrm{H}_{2}$ concentrations is bimodal in shape, with an upper bound of $78 \%$. It will be interesting to see if future data will continue to show such a shape, and thus suggest that the limiting (or parent) distribution is indeed bimodal.

In conclusion, the results of this analysis indicate that under favorable sampling conditions, DS grab samples can provide reasonably accurate information about the dominant species of released gas. To assure such favorable conditions, it is recommended that DS grab sampling be requested for argon-purged activities. This recommendation supports the requirement to collect more data for elevated LFL's as stated in the current Data Quality Objective document (Bauer 1998, section 4.3.1, criterion 6). 


\subsection{REFERENCES}

Bauer, R. E. and Jackson, L. P., 1998, Data Quality Objective to Support Resolution of the Flammable Gas Safety Issue, HNF-SD-WM-DQO-004, Rev.3-A, Duke Engineering Services Hanford, Inc.

Lide, D. and Frederikse, H., Eds., 1994, "U.S. Standard Atmosphere (1976)," listed in the CRC Handbook of Chemistry and Physics, $75^{\text {th }}$ Edition, CRC Press, Inc.

Mahoney, L., et al., 1997, Composition and Quantities of Retained Gas Measured in Hanford Waste Tanks 241-U-103, S-106, BY-101, and BY-109, Pacific Northwest National Laboratory document PNNL-11777.

Shekkariz, A., et al., 1997, Composition and Quantities of Retained Gas Measured in Hanford Waste Tanks 241-AW-101, A-101, AN-105, AN-104, and AN-103," Pacific Northwest National Laboratory document PNNL-1 1450 Rev.1. 


\subsection{GLOSSARY}

ACL Analytic Chemistry Laboratory

ALO Analytic Chemistry Office

ASR Analytic Services Request

CFE Characterization Field Engineering

$\mathrm{CoC}$ Chain-of-Custody

CPO Characterization Project Office

DRI Direct Reading Instrument

DS Drill String

IH\&S Industrial Hygiene \& Safety

PNNL Pacific Northwest National Laboratory

RGS Retained Gas Sampler 


\subsection{APPENDIX}

This section contains the tables of all the data referenced in body of this report. Note that the convention for reporting values of uncertainty in these tables is the standard method adopted throughout this report: Unless displayed, the uncertainty in any listed value is $+/-$ one unit in the last significant figure. Unless stated otherwise, all calculated uncertainties will be determined by using the correlated error propagation procedure, i.e. "sums of errors" rules, instead of the uncorrelated error propagation procedure, i.e. "sums of errors squared" rules. The choice of the larger uncertainty is consistent with the overall (conservative) approach taken in this report.

Notes for Tables 1.a-1.d:

The data in these tables are taken from the four primary documents referenced in the Methods sections 3.1 and 3.2. Each table is divided into five blocks, labeled ACL Report Number \& Analysis Date, \% Mole Fractions, Useful Combinations, Additional Information, and CGM Readings. The mole fraction values reported were in vol.\% of "dry" gas (omitting water vapor). Also note that the Mass Spec calibration regiment includes daily $\mathrm{N}_{2}$.and weekly "air" calibration tests, and the precision of values reported (statistical errors) were usually less than $2 \%$.

The following list contains the definitions of the symbols used as non-numeric entries or footnotes in the tables.

$\mathrm{NA}=$ Not Applicable

$\mathrm{N} / \mathrm{R}=$ No value Recorded

For the Footnotes, lower case symbols refer to ALO reports, upper case to IH-DRI surveys.

a) Hydrocarbon values were estimated using methane, ethane, and butane as calibration species.

q) Quill Rod Sample

A) The GCM used by IH tech failed post-measurement calibration test after $34 \%$ LEL .

D) Conflicting order of recorded Dates.

O) High Organic vapor values in IH-DRI survey consistent with Mass Spec results.

M) Missing IH-DRI survey.

3MO) Sample taken after 3 month delay in activity.

SRD) Sample Release Delayed 
HNF-1754 Rev.0

This page intentionally left blank. 


\subsection{DS Data Tables}

\section{Table 8.1.a: Possible DS Data}

\begin{tabular}{|c|c|c|c|c|c|c|c|c|c|c|c|c|c|c|}
\hline \multicolumn{15}{|c|}{ ACL (Mass Spec) Report Number \& Analysis Date - Part 1a } \\
\hline ALO No. & \multicolumn{2}{|c|}{95.09000} & \multicolumn{2}{|c|}{$96-00695$} & \multicolumn{2}{|c|}{$96-01330$} & \multicolumn{2}{|c|}{$96-02338$} & \multicolumn{2}{|c|}{$96-02453$} & \multicolumn{2}{|c|}{$96-02800$} & \multicolumn{2}{|c|}{$96-02859$} \\
\hline Analyzed & \multicolumn{2}{|c|}{ 9/27/95 } & \multicolumn{2}{|c|}{$10 / 26 / 95$} & \multicolumn{2}{|c|}{$11 / 20 / 95$} & \multicolumn{2}{|c|}{$12 / 28 / 96$} & \multicolumn{2}{|c|}{$1 / 4 / 96$} & \multicolumn{2}{|c|}{$1 / 15 / 96$} & \multicolumn{2}{|c|}{$1 / 17 / 96$} \\
\hline \multicolumn{15}{|c|}{ Mole Fractions (vol. $\%$ mean \& stnd) } \\
\hline $\mathrm{Ar}$ & 0.94 & 0.02 & 0.125 & 0.03 & 0.96 & 0.02 & 0.87 & 0.02 & 0.005 & 0.001 & 0.293 & 0.006 & 0.18 & 0.004 \\
\hline $\mathrm{CO} 2$ & 0.052 & 0.005 & $<0.01$ & & 0.028 & 0.001 & 0.061 & 0.006 & $<0.01$ & & $<0.01$ & & $<0.005$ & \\
\hline $\mathrm{CO}$ & $<0.01$ & & $<0.01$ & & $<0.01$ & & $\mathrm{~N} / \mathrm{R}$ & & $<0.01$ & & $<0.01$ & & $<0.01$ & \\
\hline $\mathrm{He}$ & $<0.001$ & & $<0.001$ & & $<0.001$ & & $<0.001$ & & $<0.001$ & & $<0.001$ & & $<0.001$ & \\
\hline $\mathrm{H2}$ & 0.68 & 0.02 & 24.0 & 0.5 & 0.315 & 0.006 & 1.44 & 0.03 & 6.2 & 0.1 & 2.69 & 0.05 & 0.65 & 0.01 \\
\hline $\mathrm{CH} 4$ & 0.0011 & 0 & 0.83 & 0.04 & 0 & 0 & 0.006 & 0.003 & 0.08 & 0.01 & 0.021 & 0.001 & 0.011 & 0.02 \\
\hline $\mathrm{N} 2$ & 78.0 & 0.4 & 57.1 & 0.6 & 79.9 & 0.4 & 78.2 & 0.4 & 88.3 & 0.1 & 89.3 & 0.1 & 94.87 & 1.90 \\
\hline $\mathrm{O} 2$ & 20.2 & 0.4 & 1.17 & 0.02 & 18.8 & 0.4 & 19.2 & 0.4 & 0.047 & 0.004 & 6.1 & 0.1 & 3.86 & 0.08 \\
\hline $\mathrm{N} 2 \mathrm{O}$ & 0.09 & 0.009 & 14.9 & 0.3 & $<0.01$ & & 0.28 & 0.02 & 5.3 & 0.1 & 1.61 & 0.03 & 0.423 & 0.009 \\
\hline Other NOx & $<0.005$ & & $<0.005$ & & $<0.005$ & & $<0.01$ & & 0.05 & 0.005 & $<0.005$ & & $<0.005$ & \\
\hline $\mathrm{C} 2 \mathrm{Hx}$ & $\mathrm{N} / \mathrm{R}$ & & 1.11 & 0.02 & $<0.001$ & & $<0.001$ & & 0.02 & 0.01 & $<0.001$ & & $<0.001$ & \\
\hline Other CxHy & $<0.001$ & & 0.61 & 0.06 & $<0.001$ & & $<0.001$ & & $<0.001$ & & $<0.001$ & & $<0.001$ & \\
\hline $\mathrm{NH} 3$ (est.) & $<0.01$ & & 0.28 & 0.03 & $<0.001$ & & N/R & & $<0.01$ & & $<0.001$ & & $\mathrm{~N} / \mathrm{R}$ & \\
\hline \multicolumn{15}{|c|}{ Useful Combinations (of above data) } \\
\hline $\mathrm{N} 2+\mathrm{O} 2+\mathrm{Ar}$ & 99.14 & 0.82 & 58.40 & 0.65 & 99.66 & 0.82 & 98.27 & 0.82 & 88.35 & 0.11 & 95.69 & 0.21 & 98.91 & 1.98 \\
\hline $\mathrm{N} 2 / \mathrm{O} 2$ & 3.86 & & 48.80 & & 4.25 & & 4.07 & & 1878.72 & & 14.64 & & 24.58 & \\
\hline $\mathrm{Ar} / \mathrm{O} 2$ & 0.047 & & 0.107 & & 0.051 & & 0.045 & & 0.106 & & 0.048 & & 0.047 & \\
\hline \%FL(H2) & 17.00 & & 600.00 & & 7.88 & & 36.00 & & 155.00 & & 67.25 & & 16.25 & \\
\hline \multicolumn{15}{|c|}{ Additional Information (from other sources) } \\
\hline Tank/Riser & S-107 & $\mathrm{R}-2$ & BY -110 & $\mathrm{~N} / \mathrm{R}$ & B-203 & $\mathrm{R}-6$ & $\mathrm{U}-109$ & $\mathrm{~N} / \mathrm{R}$ & U-109 & R-2 & $S-102$ & $\mathrm{~N} / \mathrm{R}$ & $\mathrm{U}-109$ & R-7 \\
\hline Survey No. & \multicolumn{2}{|c|}{$95-0568$} & \multicolumn{2}{|c|}{$95-1063$} & \multicolumn{2}{|c|}{$95-0898$} & \multicolumn{2}{|c|}{$95-1011^{*}$} & \multicolumn{2}{|c|}{ 96-0527* } & \multicolumn{2}{|c|}{ 96-0455* } & $\mathrm{NA}$ & \\
\hline Sampled & 9/27/95 & & $10 / 24 / 95$ & & $11 / 17 / 95$ & & $12 / 28 / 95$ & & $1 / 4 / 96$ & & $1 / 12 / 96$ & & $1 / 16 / 96$ & \\
\hline Purge Gas & $\mathrm{Ar}$ & & $\mathrm{N} 2$ & & $\mathrm{Ar}$ & & N2 & & $\mathrm{N} 2$ & & N2 & & $\mathrm{N} 2$ & \\
\hline \multicolumn{15}{|c|}{ CGM Readings (from IH\&S DRI Surveys) } \\
\hline $0.5 \%$ LEL & 26.00 & & 167.00 & & 9 & & 117.00 & & 143.00 & & \multicolumn{2}{|c|}{ Off Scale } & $N / R$ & \\
\hline$\% \mathrm{O} 2$ & 20.8 & & 0.3 & & 19.3 & & $\mathrm{~N} / \mathrm{R}$ & & 12 & & 12.3 & & $\mathrm{~N} / \mathrm{R}$ & \\
\hline & & & & & & & & & & & & & & \\
\hline (Footnotes) & (M) & & $(\mathrm{a}, \mathrm{A}, \mathrm{O})$ & & (1) & & (1) & & 0 & & 0 & & $(\mathrm{~g},)^{2}$ & \\
\hline
\end{tabular}


Table 8.1.b: Possible DS Data (continued)

\begin{tabular}{|c|c|c|c|c|c|c|c|c|c|c|c|c|}
\hline \multicolumn{13}{|c|}{ ACL (Mass Spec) Report Number \& Analysis Date -. Part $1 \mathrm{~b}$} \\
\hline ALO No. & \multicolumn{2}{|c|}{ 96-03279 } & \multicolumn{2}{|c|}{$96-03482$} & \multicolumn{2}{|c|}{ 96-03499 } & \multicolumn{2}{|c|}{$96-03500$} & \multicolumn{2}{|c|}{$96-03501$} & \multicolumn{2}{|c|}{$96-03502$} \\
\hline Analyzed & \multicolumn{2}{|c|}{$02 / 16 / 96$} & \multicolumn{2}{|c|}{$02 / 28 / 96$} & \multicolumn{2}{|c|}{$02 / 29 / 96$} & \multicolumn{2}{|c|}{$02 / 29 / 96$} & \multicolumn{2}{|c|}{$02 / 29 / 96$} & \multicolumn{2}{|c|}{$02 / 29 / 96$} \\
\hline \multicolumn{13}{|c|}{ Mole Fractions (vol.\% mean \&stnd) } \\
\hline Ar & 0.125 & 0.003 & 0.91 & 0.02 & 0.94 & 0.02 & 0.94 & 0.02 & 0.94 & 0.02 & 0.94 & 0.02 \\
\hline $\mathrm{CO} 2$ & $<0.001$ & & $<0.01$ & & 0.037 & 0.004 & 0.053 & 0.005 & 0.039 & 0.004 & 0.037 & 0.004 \\
\hline $\mathrm{CO}$ & $<0.01$ & & $<0.01$ & & $<0.01$ & & $<0.01$ & & $<0.01$ & & $<0.01$ & \\
\hline $\mathrm{He}$ & $<0.001$ & & $<0.001$ & & $<0.001$ & & $<0.001$ & & $<0.001$ & & $<0.001$ & \\
\hline $\mathrm{H} 2$ & 2.14 & 0.04 & 2.96 & 0.06 & $<0.001$ & & 0.222 & 0.004 & $<0.001$ & & $<0.001$ & \\
\hline Cres 4 & $<0.001$ & & $<0.001$ & & $<0.001$ & & $<0.001$ & & $<0.001$ & & $<0.001$ & \\
\hline N2 & 95.2 & 0.06 & 77.4 & 0.4 & 78.0 & 0.4 & 77.7 & 0.4 & 77.9 & 0.4 & 78.0 & 0.4 \\
\hline $\mathrm{O} 2$ & 2.37 & 0.05 & 18.5 & 0.4 & 21.0 & 0.4 & 21.1 & 0.4 & 21.1 & 0.4 & 21.1 & 0.4 \\
\hline $\mathrm{N} 2 \mathrm{O}$ & 0.174 & 0.003 & 0.236 & 0.005 & $<0.005$ & & $<0.005$ & & $<0.005$ & & $<0.005$ & \\
\hline Other Nox & $<0.005$ & & $<0.005$ & & $<0.005$ & & $<0.005$ & & $\leq 0.005$ & & $<0.005$ & \\
\hline $\mathrm{C} 2 \mathrm{Hx}$ & $<0.001$ & & $<0.001$ & & $<0.001$ & & $<0.001$ & & $<0.001$ & & $<0.001$ & \\
\hline Other $\mathrm{CxHy}$ & $<0.001$ & & $<0.001$ & & $<0.001$ & & $<0.001$ & & $<0.001$ & & $<0.001$ & \\
\hline $\mathrm{NH} 3$ (est.) & $\mathrm{N} / \mathrm{R}$ & & $\mathrm{N} / \mathrm{R}$ & & $\mathrm{N} / \mathrm{R}$ & & $N / R$ & & $N / R$ & & $\mathrm{~N} / \mathrm{R}$ & \\
\hline \multicolumn{13}{|c|}{ Useful Combinations (of above data) } \\
\hline $\mathrm{N} 2+\mathrm{O} 2+\mathrm{Ar}$ & 97.70 & 0.11 & 96.81 & 0.82 & 99.94 & 0.82 & 99.74 & 0.82 & 99.94 & 0.82 & 100.04 & 0.82 \\
\hline $\mathrm{N} 2 / \mathrm{O} 2$ & 40.17 & & 4.18 & & 3.71 & & 3.68 & & 3.69 & & 3.70 & \\
\hline $\mathrm{Ar} / \mathrm{O} 2$ & 0.053 & & 0.049 & & 0.045 & & 0.045 & & 0.045 & & 0.045 & \\
\hline$\% \mathrm{LFL}(\mathrm{H} 2)$ & 53.50 & & 74.00 & & $N / R$ & & 5.55 & & $N / R$ & & $\mathrm{~N} / \mathrm{R}$ & \\
\hline \multicolumn{13}{|c|}{ Additional Information (from other sources) } \\
\hline Tank / Riser & $S=102$ & $\mathrm{R}-14$ & AW-101 & & \multicolumn{2}{|c|}{ AR Vault } & \multicolumn{2}{|c|}{ AR Vault } & \multicolumn{2}{|c|}{ AR Vault } & \multicolumn{2}{|c|}{ AR Vault } \\
\hline Survey No. & \multicolumn{2}{|c|}{ 96-0402 } & NA & & \multicolumn{2}{|c|}{$96-0495$} & \multicolumn{2}{|c|}{ 96-0495 } & \multicolumn{2}{|c|}{$96-0495$} & \multicolumn{2}{|c|}{ 96-0495 } \\
\hline Sampled & $02 / 09 / 96$ & & $02 / 27 / 96$ & & $02 / 29 / 96$ & & $02 / 29 / 96$ & & $02 / 29 / 96$ & & $02 / 29 / 96$ & \\
\hline Purge Gas & $\mathrm{N} 2$ & & $\mathrm{Ar}$ & & NA & & NA & & $\mathrm{NA}$ & & NA & \\
\hline \multicolumn{13}{|c|}{ CGM Readings (from IH\&S DRI Surveys) } \\
\hline $0.5 \% \mathrm{LEL}$ & 89.00 & & $\mathrm{~N} / \mathrm{R}$ & & NA & & NA & & $\mathrm{NA}$ & & NA & \\
\hline$\% \mathrm{O} 2$ & 16.8 & & $\mathrm{~N} / \mathrm{R}$ & & NA & & NA & & NA & & NA & \\
\hline & & & & & & & & & & & & \\
\hline (Footnotes) & () & & () & & () & & () & & 0 & & () & \\
\hline
\end{tabular}


Table 8.1.c: Possible DS Data (continued)

\begin{tabular}{|c|c|c|c|c|c|c|c|c|c|c|c|c|}
\hline \multicolumn{13}{|c|}{ ACL (Mass Spec) Report Number \& Analysis Date - Part lc } \\
\hline ALONo. & \multicolumn{2}{|c|}{$96-06694$} & \multicolumn{2}{|c|}{$96-06721$} & \multicolumn{2}{|c|}{$97-00009$} & \multicolumn{2}{|c|}{$97-01471$} & \multicolumn{2}{|c|}{$97-01472$} & \multicolumn{2}{|c|}{$97-01967$} \\
\hline Analyzed & \multicolumn{2}{|c|}{$09 / 13 / 96$} & \multicolumn{2}{|c|}{$09 / 17 / 96$} & $10 / 02 / 96$ & & \multicolumn{2}{|c|}{$01 / 08 / 97$} & \multicolumn{2}{|c|}{$01 / 08 / 97$} & \multicolumn{2}{|c|}{$02 / 25 / 97$} \\
\hline \multicolumn{13}{|c|}{ Mole Fractions (vol.\% mean \& stnd.)) } \\
\hline $\mathrm{Ar}$ & 45.1 & 0.8 & 36.3 & 0.9 & 0.96 & 0.02 & 0.97 & 0.03 & 0.96 & 0.03 & 0.86 & 0.02 \\
\hline $\mathrm{CO} 2$ & $<0.01$ & & $<0.01$ & & $<0.01$ & & 0.04 & 0.004 & 0.05 & 0.005 & $<0.05$ & \\
\hline $\mathrm{CO}$ & $<0.01$ & & $<0.01$ & & $<0.01$ & & $<0.01$ & & $<0.01$ & & $<0.05$ & \\
\hline $\mathrm{He}$ & $<0.001$ & & $<0.001$ & & $<0.001$ & & $<0.001$ & & $<0.001$ & & 2.22 & 0.04 \\
\hline $\mathrm{H} 2$ & 6.8 & 0.1 & 9.6 & 0.2 & 0.133 & 0.003 & 0.0036 & 0.0005 & 0.0025 & 0.0005 & 6.31 & 0.06 \\
\hline $\mathrm{CH} 4$ & 0.183 & 0.004 & 0.041 & 0.002 & 0.004 & 0.001 & $<0.001$ & & $<0.001$ & & $<0.001$ & \\
\hline $\mathrm{N} 2$ & 38.2 & 0.8 & 43.8 & 0.9 & 77.6 & 0.4 & 79.5 & 0.4 & 79.4 & 0.4 & 71.7 & 0.3 \\
\hline $\mathrm{O} 2$ & 7.3 & 0.1 & 9.2 & 0.2 & 21.1 & 0.4 & 19.5 & 0.4 & 19.6 & 0.4 & 17.3 & 0.3 \\
\hline $\mathrm{N} 2 \mathrm{O}$ & 2.29 & 0.05 & 1.04 & 0.02 & 0.22 & 0.004 & 0.0017 & 0.0008 & 0.0014 & 0.0008 & 1.57 & 0.03 \\
\hline Other NOX & $<0.005$ & & $<0.005$ & & $<0.005$ & & $<0.005$ & & $<0.005$ & & $<0.005$ & \\
\hline$\overline{\mathrm{C} 2 \mathrm{Hx}}$ & 0.104 & 0.002 & 0.047 & 0.002 & $<0.001$ & & $<0.001$ & & $<0.001$ & & 0.021 & 0.004 \\
\hline Other CxHy & 0.01 & 0.005 & 0.02 & 0.005 & $<0.001$ & & $<0.001$ & & $<0.001$ & & 0.015 & 0.004 \\
\hline $\mathrm{NH} 3$ (est.) & $<0.001$ & & $<0.001$ & & $<0.005$ & & $\mathrm{~N} / \mathrm{R}$ & & $\mathrm{N} / \mathrm{R}$ & & $<0.1$ & \\
\hline \multicolumn{13}{|c|}{ Useful Combinations (of above data) } \\
\hline $\mathrm{N} 2+\mathrm{O} 2+\mathrm{Ar}$ & 90.6 & 1.7 & 89.3 & 2.0 & 99.7 & 0.8 & 100.0 & 0.8 & 100.0 & 0.8 & 89.9 & 0.6 \\
\hline $\mathrm{N} 2 / \mathrm{O} 2$ & 5.23 & & 4.76 & & 3.68 & & 4.08 & & 4.05 & & 4.14 & \\
\hline $\mathrm{Ar} / \mathrm{O} 2$ & 6.178 & & 3.946 & & 0.045 & & 0.050 & & 0.049 & & 0.050 & \\
\hline$\% \mathrm{LFL}(\mathrm{H} 2)$ & 170.0 & & 240.0 & & 3.3 & & 0.1 & & 0.1 & & 157.8 & \\
\hline \multicolumn{13}{|c|}{ Additional Information (from other sources) } \\
\hline Tank/Riser & AN-104 & R-10A & $\mathrm{AN}-103$ & $\mathrm{R}-12 \mathrm{~A}$ & $\mathrm{U}-103$ & R-2 & U-103. & $\mathrm{R}-2$ & $\mathrm{U}-103$ & $\mathrm{R}-2$ & S-106 & $\mathrm{R}-7$ \\
\hline Survey No. & $N / R$ & & $? ?$ & & \multicolumn{2}{|c|}{ 96-1985 } & \multicolumn{2}{|c|}{ 96-0004 } & \multicolumn{2}{|c|}{ 96-0004 } & \multicolumn{2}{|c|}{ 96-0060 } \\
\hline Sampled & $09 / 12 / 96$ & & $09 / 16 / 96$ & & $10 / 01 / 96$ & & $01 / 08 / 97$ & & $01 / 08 / 97$ & & $02 / 25 / 97$ & \\
\hline Purge Gas & $\mathrm{Ar}$ & & $\mathrm{Ar}$ & & $\mathrm{Ar}$ & & $\mathrm{Ar}$ & & $\mathrm{Ar}$ & & $\mathrm{Ar}$ & \\
\hline \multicolumn{13}{|c|}{ CGM Readings (from IH\&S DRI Surveys) } \\
\hline $0.5 \% \mathrm{LEL}$ & $450^{*}$ & & $264 *$ & & $\mathrm{~N} / \mathrm{R}$ & & $\mathrm{N} / \mathrm{R}$ & & $\mathrm{N} / \mathrm{R}$ & & 234.00 & \\
\hline$\% \mathrm{O} 2$ & $\mathrm{~N} / \mathrm{R}$ & & $\mathrm{N} / \mathrm{R}$ & & $\mathrm{N} / \mathrm{R}$ & & $\mathrm{N} / \mathrm{R}$ & & $\mathrm{N} / \mathrm{R}$ & & $\mathrm{N} / \mathrm{R}$ & \\
\hline & & & & & & & & & & & & \\
\hline (Footnotes) & () & & () & & () & & $(3 \mathrm{MO})$ & & $(3 \mathrm{MO})$ & & () & \\
\hline
\end{tabular}


Table 8.1.d: Possible DS Data (continued)

\begin{tabular}{|c|c|c|c|c|c|c|c|c|c|c|c|c|c|c|}
\hline \multicolumn{15}{|c|}{ ACL (Mass Spec) Report Number \& Analysis Date - Part 1d } \\
\hline ALONo. & \multicolumn{2}{|c|}{$97-02124$} & \multicolumn{2}{|c|}{$97-02125$} & \multicolumn{2}{|c|}{ 97-02775 } & \multicolumn{2}{|c|}{$97-02794$} & \multicolumn{2}{|c|}{$97-03541$} & \multicolumn{2}{|c|}{ 97-04398 } & \multicolumn{2}{|c|}{ 98-00508 } \\
\hline Analyzed & \multicolumn{2}{|c|}{$3 / 3 / 97$} & \multicolumn{2}{|c|}{$3 / 3 / 97$} & \multicolumn{2}{|c|}{$4 / 7 / 97$} & \multicolumn{2}{|c|}{$4 / 7 / 97$} & \multicolumn{2}{|c|}{$6 / 17 / 97$} & \multicolumn{2}{|c|}{$8 / 14 / 97$} & \multicolumn{2}{|c|}{$10 / 30 / 97$} \\
\hline \multicolumn{15}{|c|}{ Mole Fractions (vol.\% mean \& stnd.) } \\
\hline Ar & 81.0 & 0.2 & 0.99 & 0.02 & 0.94 & 0.02 & 0.94 & 0.02 & 0.90 & 0.02 & 7.8 & 0.2 & 1 & 0.02 \\
\hline $\mathrm{CO} 2$ & 0.013 & 0.005 & 0.029 & 0.003 & 0.043 & 0.004 & 0.049 & 0.005 & $<0.01$ & & 0.06 & 0.02 & 0.041 & 0.004 \\
\hline $\mathrm{CO}$ & $<0.01$ & & $<0.01$ & & $<0.01$ & & $<0.01$ & & $<0.01$ & & $<0.001$ & & $<0.01$ & \\
\hline $\mathrm{He}$ & 0.128 & 0.003 & $<0.001$ & & $<0.001$ & & $<0.001$ & & 0.17 & 0.003 & $<0.001$ & & 0.456 & 0.009 \\
\hline $\mathrm{H} 2$ & 4.79 & 0.09 & 0.066 & 0.002 & $<0.001$ & & $<0.001$ & & 2.95 & 0.06 & 0.63 & 0.02 & 0.78 & 0.02 \\
\hline $\mathrm{CH} 4$ & 0.013 & 0.003 & $<0.001$ & & $<0.001$ & & $<0.001$ & & 0.052 & 0.002 & 0.004 & 0.001 & 0.005 & 0 \\
\hline N2 & 10.8 & 0.2 & 79.1 & 0.4 & 77.8 & 0.4 & 77.8 & 0.4 & 76.0 & 0.4 & 77.4 & 0.4 & 83.7 & 0.3 \\
\hline $\mathrm{O} 2$ & 2.43 & 0.05 & 19.8 & 0.4 & 21.2 & 0.4 & 21.2 & 0.4 & 19.0 & 0.4 & 14.0 & 0.4 & 13.7 & 0.3 \\
\hline $\mathrm{N} 2 \mathrm{O}$ & 0.76 & 0.04 & 0.003 & 0.001 & $<0.001$ & & $<0.001$ & & 0.88 & 0.02 & 0.08 & 0.02 & 0.312 & 0.006 \\
\hline Other NOx & $<0.005$ & & $<0.005$ & & $<0.005$ & & $<0.005$ & & $<0.05$ & & $<0.005$ & & $<0.005$ & \\
\hline $\mathrm{C} 2 \mathrm{Hx}$ & 0.01 & 0.005 & 0.004 & 0.002 & $<0.001$ & & $<0.001$ & & $N / R$ & & $<0.001$ & & $<0.001$ & \\
\hline Other CxHy & 0.005 & 0.003 & $<0.001$ & & $<0.001$ & & $<0.001$ & & 0.10 & 0.05 & $\mathrm{~N} / \mathrm{R}$ & & $\mathrm{N} / \mathrm{R}$ & \\
\hline $\mathrm{NH3}$ (est.) & $<0.1$ & & $\mathrm{~N} / \mathrm{R}$ & & $\mathrm{N} / \mathrm{R}$ & & $\mathrm{N} / \mathrm{R}$ & & $N / R$ & & N/R & & $\mathrm{N} / \mathrm{R}$ & \\
\hline \multicolumn{15}{|c|}{ Useful Combinations (of above data) } \\
\hline $\mathrm{N} 2+\mathrm{O} 2+\mathrm{Ar}$ & 94.2 & 0.5 & 99.9 & 0.8 & 99.9 & 0.8 & 99.9 & 0.8 & 95.9 & 0.8 & 99.2 & 1.0 & 98.4 & 0.6 \\
\hline $\mathrm{N} 2 / \mathrm{O} 2$ & 4.44 & & 3.99 & & 3.67 & & 3.67 & & 4.00 & & 5.53 & & 6.11 & \\
\hline $\mathrm{Ar} / \mathrm{O} 2$ & 33.333 & & 0.050 & & 0.044 & & 0.044 & & 0.047 & & 0.557 & & 0.073 & \\
\hline$\% \mathrm{LFL}(\mathrm{H} 2)$ & 119.8 & & 1.7 & & $\mathrm{~N} / \mathrm{R}$ & & $\mathrm{N} / \mathrm{R}$ & & 73.8 & & 15.8 & & 19.5 & \\
\hline \multicolumn{15}{|c|}{ Additional Information (from other sources) } \\
\hline Tank/Riser & S-106 & $\mathrm{R}-7$ & S-106 & $\mathrm{R}-8$ & U-103 & & U-103 & & BY-109 & & SY-102 & & SX-106 & R-6 \\
\hline Survey No. & $97-0063^{*}$ & & $97-0049 *$ & & $97-0146^{*}$ & & $97-0146^{*}$ & & $97-0851$ & & $97-1076$ & & $97-1481$ & \\
\hline Sampled & $2 / 25 / 97$ & & $2 / 18 / 97$ & & $4 / 7 / 97^{*}$ & & $4 / 7 / 97$ & & $6 / 17 / 97$ & & $8 / 13 / 97$ & & $10 / 29 / 97$ & \\
\hline Purge Gas & $\mathrm{Ar}$ & & $\mathrm{Ar}$ & & Ar & & Ar & & Ar & & $\mathrm{Ar}$ & & $\mathrm{Ar}$ & \\
\hline \multicolumn{15}{|c|}{ CGM Readings (from IH\&S DRI Surveys) } \\
\hline $0.5 \%$ LEL & $\mathrm{N} / \mathrm{R}$ & & $\mathrm{N} / \mathrm{R}$ & & $?$ & & $?$ & & $?$ & & No DRI & & No DRI & \\
\hline$\% \mathrm{O} 2$ & $\mathrm{~N} / \mathrm{R}$ & & $\mathrm{N} / \mathrm{R}$ & & & & & & & & & & & \\
\hline & & & & & & & & & & & & & & \\
\hline (Footnotes) & $(\mathrm{SRD})$ & & $(\mathrm{SRD})$ & & (I) & & (I) & & () & & $(\mathrm{M})$ & $+/-$ & {$[,] \square(\mathrm{M})$} & $+/-$ \\
\hline
\end{tabular}




\subsection{Documented Information}

\section{Table 8.2.a: Document Info}

\begin{tabular}{|c|c|c|c|c|c|}
\hline $\begin{array}{l}\text { ALO No. } \\
\text { Survey No. } \\
\text { DRI found? }\end{array}$ & $\begin{array}{l}\text { Date - Time Sampled } \\
\text { Date - Time Shipped } \\
\text { Date - Time Received }\end{array}$ & $\begin{array}{l}\text { Sampled by } \\
\text { Received by }\end{array}$ & $\begin{array}{l}\text { Tank / Riser } \\
\text { (Purge Gas) } \\
\text { [ Info Source ] }\end{array}$ & $\begin{array}{l}\text { DRI Survey } \\
\text { Data ( CGM) } \\
\% \text { LEL \& \%O2 }\end{array}$ & Comments \\
\hline $\begin{array}{l}95-09000 \\
95-0568 \\
Y\end{array}$ & $\begin{array}{l}9 / 27 / 95-17: 22 \\
9 / 27 / 95- \\
9 / 27 / 95-6: 56(\mathrm{pm} ?)\end{array}$ & $\begin{array}{l}\text { K.L. Newcomb } \\
\text { M.W. Goheen }\end{array}$ & $\begin{array}{l}\text { S-107, R-2 } \\
\text { ( Ar) } \\
\text { [ACL Report, DRI] }\end{array}$ & $\begin{array}{l}\text { LEL: } 51 \% \\
\text { O2: } 20.8 \%\end{array}$ & Drill String is noted as location in DRI. \\
\hline $\begin{array}{l}96-01330 \\
95-0898 \\
Y\end{array}$ & $\begin{array}{l}11 / 17 / 95-13: 30 \\
11 / 17 / 95- \\
11 / 20 / 95-10: 30\end{array}$ & $\begin{array}{l}\text { D. Spaulding } \\
\text { M.W. Goheen }\end{array}$ & $\begin{array}{l}\text { B-203, R-6 } \\
\text { (Ar) } \\
{[\mathrm{CoC}, \mathrm{DRI}]}\end{array}$ & $\begin{array}{l}\text { LEL: } 18 \% \\
\text { O2: } 19.3 \%\end{array}$ & Drill String is noted as location in DRI. \\
\hline $\begin{array}{l}96-02338 \\
95-0994 * \\
Y^{*}\end{array}$ & $\begin{array}{l}12 / 28 / 95-\mathrm{N} / \mathrm{R} \\
12 / 28 / 95- \\
12 / 28 / 95-12: 59\end{array}$ & $\begin{array}{l}\text { P.J. Coppersmith } \\
\text { M.W. Goheen }\end{array}$ & $\begin{array}{l}\text { U-109, N/R } \\
\text { (N2) } \\
\text { [ASR, CFE Log] }\end{array}$ & $\begin{array}{l}\text { LEL: } 235 \% \\
\text { O2: N/R }\end{array}$ & $\begin{array}{l}\text { *No DRI found for Survey No.95-0994 (listed on CoC). } \\
\text { However, info on Survey No.95-1011 (in IH\&S files) for } \\
\text { this tank, date and surveyor is consistent with all other info. } \\
\text { From the writing on the DRI, it appears that the no. } 95-1011 \\
\text { was entered by someone other than the surveyor. }\end{array}$ \\
\hline $\begin{array}{l}96-02453 \\
96-0527 * * \\
Y\end{array}$ & $\begin{array}{l}1 / 4 / 96-10: 15 \\
1 / 4 / 96- \\
1 / 4 / 96-14: 08\end{array}$ & $\begin{array}{l}\text { K.Q. Junt } \\
\text { M.W. Goheen }\end{array}$ & $\begin{array}{l}\text { U-109, R-2 } \\
\text { (N2) } \\
\text { [ASR, DRI, CFE Log] }\end{array}$ & $\begin{array}{l}\text { LEL: } 285 \% \\
\text { O2: } 12 \%\end{array}$ & $\begin{array}{l}\text { ** Survey number is NOT recorded on CoC. DRI obtained } \\
\text { from surveyor (not in IH\&S files). } \\
\text { "U-109" is recorded as the sample id on ASR. } \\
\text { Drill String is noted as location in DRI. }\end{array}$ \\
\hline $\begin{array}{l}96-02800 \\
96-0455 * * \\
Y\end{array}$ & $\begin{array}{l}1 / 12 / 96-20: 30 \\
1 / 15 / 96- \\
1 / 15 / 96-13: 53\end{array}$ & $\begin{array}{l}\text { D. Spaulding } \\
\text { S.G. Bos }\end{array}$ & $\begin{array}{l}\mathrm{S}-102, \mathrm{~N} / \mathrm{R} \\
(\mathrm{N} 2) \\
\text { [ASR, DRI] }\end{array}$ & $\begin{array}{l}\text { LEL: Off Scale } \\
(>500 \%) \\
\text { O2: } 12.3 \%\end{array}$ & $\begin{array}{l}\text { ** Survey number is NOT recorded on CoC. DRI obtained } \\
\text { from surveyor (not in IH\&S files). } \\
\text { "S-102 Drill String[] is recorded as sample id on ASR. }\end{array}$ \\
\hline $\begin{array}{l}96-02859 \\
\text { NA } \\
\text { NA }\end{array}$ & $\begin{array}{l}1 / 16 / 96-8: 30 \\
1 / 17 / 96- \\
1 / 17 / 96-13: 00\end{array}$ & $\begin{array}{l}\text { J.A. Paýne } \\
\text { M.W. Goheen }\end{array}$ & $\begin{array}{l}\text { U-109, R-7 } \\
\text { (N2) } \\
\text { [ASR, SC, CFE Log] }\end{array}$ & $\begin{array}{l}\text { LEL: N/R } \\
\text { O2: N/R }\end{array}$ & $\begin{array}{l}\text { "Quill Rod Truck \#3D is recorded as sample id on ASR. } \\
\text { DRI was not required because no drill operation in progress } \\
\text { at time of sample (2nd shift). Sample taken from gas sealed } \\
\text { in quill rod at (weather-caused) shut down on previous shift. }\end{array}$ \\
\hline
\end{tabular}


Table 8.2.b: Document Info (continued)

\begin{tabular}{|c|c|c|c|c|c|}
\hline $\begin{array}{l}96-03482 \\
\text { NA } \\
\text { NA }\end{array}$ & $\begin{array}{l}2 / 27 / 96-15: 00 \\
2 / 27 / 96- \\
2 / 28 / 96-11: 00\end{array}$ & $\begin{array}{l}\text { K.Q. Junt } \\
\text { M.W. Goheen }\end{array}$ & $\begin{array}{l}\text { AW-101, N/R } \\
\text { (Ar) } \\
\text { [ASR, CFEDs Log] }\end{array}$ & $\begin{array}{l}\text { LEL: N/R } \\
\text { O2: N/R }\end{array}$ & $\begin{array}{l}\text { "AW-101 2-27-96-1500D is recorded as sample id on ASR. } \\
\text { Special requested grab sample did not require Survey No. or } \\
\text { DRI. }\end{array}$ \\
\hline $\begin{array}{l}96-03499 \text { to } \\
\quad-03502 \\
96-0495 \\
Y\end{array}$ & $\begin{array}{l}2 / 29 / 96-10: 00,10: 15 \\
10: 30,10: 45 \\
2 / 29 / 96- \\
2 / 29 / 96-1: 30(\mathrm{pm} ?)\end{array}$ & $\begin{array}{l}\text { R.P. Graham } \\
\text { M.W. Goheen }\end{array}$ & $\begin{array}{l}\text { 244-AR Vault } \\
\text { (NA) } \\
{[\mathrm{DRI}]}\end{array}$ & $\begin{array}{l}\text { LEL: NA } \\
\text { O2: NA }\end{array}$ & $\begin{array}{l}\text { "244-AR Control Room } \square \text { recorded as location on DRI. } \\
\text { Four (4) grab samples from "head space } \square \text { of four tanks in } \\
\text { vault. }\end{array}$ \\
\hline $\begin{array}{l}96-06694 \\
? ? \\
N\end{array}$ & $\begin{array}{l}9 / 12 / 96-9: 00 \\
9 / 13 / 96- \\
9 / 13 / 96-13: 35\end{array}$ & $\begin{array}{l}\text { J. Crocker } \\
\text { R.E. Brinson }\end{array}$ & $\begin{array}{l}\text { AN-104, R-10A } \\
\text { (AR) } \\
\text { [ASR, SC,CFE Log] }\end{array}$ & $\begin{array}{l}\text { LEL: } 900 \% \\
\text { O2: N/R }\end{array}$ & $\begin{array}{l}\text { Survey number is NOT recorded on CoC, and no DRI on file } \\
\text { for this tank, date, and surveyor. "Training } \square \text { session for } \\
\text { new IH techs (R. Horner \& S. Spencer) by J. Crocker may be } \\
\text { cause. }\end{array}$ \\
\hline $\begin{array}{l}96-06721 \\
96-1666 ? ? \\
Y ?\end{array}$ & $\begin{array}{l}9 / 16 / 96-14: 30 \\
9 / 16 / 96- \\
9 / 16 / 96-15: 44\end{array}$ & $\begin{array}{l}\text { S. Spencer? } \\
\text { S.G. Bos }\end{array}$ & $\begin{array}{l}\text { AN-103, R-12A } \\
\text { (AR) } \\
{[\mathrm{CoC}, \mathrm{DRI}, \mathrm{CFE} \log ]}\end{array}$ & $\begin{array}{l}{ }^{*} \text { LEL: } 528 \% \\
\text { O2: N/R } \\
\text { *LEL reading } \\
\text { noted on CoC. }\end{array}$ & $\begin{array}{l}\text { DRI info for Survey No.96-1666 (listed in CoC) is } \\
\text { inconsistent with CoC \& ASR info. Info on Survey No.96- } \\
1758 \text { (in IH\&S files) for this tank, date is for previous shift } \\
\text { on AN-103 (J. Crocker surveyor), and shows high LEL } \square \text { s in } \\
\text { drill string. (S. Spencer was trainee under J. Crocker.) }\end{array}$ \\
\hline $\begin{array}{l}97-00009 \\
96-1985 * \\
Y^{*}\end{array}$ & $\begin{array}{l}10 / 1 / 96-16: 30 \\
10 / 2 / 96- \\
10 / 2 / 96-09: 18\end{array}$ & $\begin{array}{l}\text { B. Brendel } \\
\text { M.W. Goheen }\end{array}$ & $\begin{array}{l}\text { U-103, R-2 } \\
\text { (Ar) } \\
{[\mathrm{CoC}, \mathrm{DRI}, \mathrm{CFE} \text { Log] }}\end{array}$ & $\begin{array}{l}\text { LEL: N/R } \\
\text { O2: N/R }\end{array}$ & 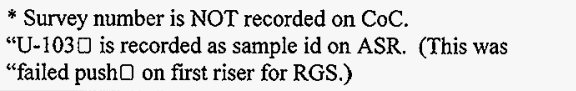 \\
\hline $\begin{array}{l}97-01471 \& \\
\quad-01472 \\
97-0004 * \\
Y^{*}\end{array}$ & $\begin{array}{l}1 / 8 / 97-01: 00 \\
1 / 8 / 97- \\
1 / 8 / 97-12: 30\end{array}$ & R.D. Melbihess & $\begin{array}{l}\text { U-103, R-2 } \\
\text { (Ar) } \\
{[\mathrm{CoC}, \mathrm{DRI}, \mathrm{CFE} \mathrm{Log}]}\end{array}$ & $\begin{array}{l}\text { LEL: } \\
\text { O2: }\end{array}$ & $\begin{array}{l}\text { * Survey number is NOT recorded on CoC. } \\
\text { U-103 "failure } \square \text { followup with } 2 \text { samples requested after } 3 \\
\text { months "soak } \square \text { with } \mathrm{H} 20+\mathrm{LiBr} \text {. }\end{array}$ \\
\hline $\begin{array}{l}97-01967^{*} \\
97-0060 \\
Y\end{array}$ & $\begin{array}{l}2 / 25 / 97-04: 45 \\
* \\
*\end{array}$ & $\begin{array}{l}\text { C.N. Hollis } \\
*\end{array}$ & $\begin{array}{l}\text { S-106, R-7 } \\
\text { (Ar) } \\
{[\text { ASR, DRI] }}\end{array}$ & $\begin{array}{l}\text { LEL: } 467 \% \\
\text { O2: } N / R\end{array}$ & $\begin{array}{l}\text { "No CoC. "S-106 Riser } 7 " \text { is recorded as sample id on ASR. } \\
\text { DRI for this tank, date, and surveyor (found in IH\&S files) } \\
\text { has record of grab sample request while monitoring drill } \\
\text { string. }\end{array}$ \\
\hline $\begin{array}{l}97-02124 \\
97-0074 * \\
Y\end{array}$ & $\begin{array}{l}2 / 25 / 97-N / R \\
3 / 3 / 97- \\
3 / 3 / 97-13: 25\end{array}$ & $\begin{array}{l}\text { J. Mickinney } \\
\text { M.W. Goheen }\end{array}$ & $\begin{array}{l}\text { S-106, R-7 } \\
\text { (Ar) } \\
\text { [ASR, DRI, CFE Log] }\end{array}$ & $\begin{array}{l}\text { LEL: N/R } \\
\text { O2: N/R }\end{array}$ & $\begin{array}{l}\text { * No DRI found for Survey No.97-0074 (listed on CoC). } \\
\text { However, info on Survey No.97-0063 (in IH\&S files) for } \\
\text { this tank, date and surveyor is consistent with all other info. } \\
\text { "Drill Sting Vapor } \square \text { noted as sample description on ASR. } \\
\text { No record of grab sample on DRI, however out-of-range } \\
\text { LEL recorded while monitoring drill string. }\end{array}$ \\
\hline
\end{tabular}


Table 8.2.c: Document Info (continued)

\begin{tabular}{|c|c|c|c|c|c|}
\hline $\begin{array}{l}97-02125 \\
97-0075 * \\
Y\end{array}$ & $\begin{array}{l}2 / 18 / 97-N / R \\
2 / 28 / 97- \\
3 / 3 / 97-13: 25\end{array}$ & $\begin{array}{l}\text { J. Mickinney } \\
\text { M.W. Goheen }\end{array}$ & $\begin{array}{l}\text { S-106, R-8 } \\
\text { (Ar) } \\
\text { [ASR, DRI, CFE Log] }\end{array}$ & $\begin{array}{l}\text { LEL: } N / R \\
\text { O2: } N / R\end{array}$ & $\begin{array}{l}\text { * No DRI found for Survey No.97-0075 (listed on CoC). } \\
\text { However, info on Survey No.97-0049 (in IH\&S files) for } \\
\text { this tank, date and surveyor is consistent with all other info. } \\
\text { "Drill Sting Vapor noted as sample description on ASR. } \\
\text { No record of grab sample on DRI, and drill string values of } \\
3 \%-25 \% \text { LEL are recorded. }\end{array}$ \\
\hline $\begin{array}{l}97-02775 \\
97-0146(?) \\
Y ?\end{array}$ & $4 / 2 / 97-$ & & & $\begin{array}{l}\text { LEL: } \\
\text { O2: }\end{array}$ & $\begin{array}{l}\text { U-103 } \\
\text { Date possibly wrong on CoC, with " } 7 \text { " changed to " } 2 \text { " and } \\
\text { later a " } 4 \text { " ?? }\end{array}$ \\
\hline $\begin{array}{l}97-02794 \\
97-0146(?) \\
Y ?\end{array}$ & $4 / 7 / 97-$ & & & $\begin{array}{l}\text { LEL: } \\
\text { O2: }\end{array}$ & $\begin{array}{l}\text { U-103 } \\
\text { Second part to above request? }\end{array}$ \\
\hline $\begin{array}{l}97-03541 \\
97-0851 \\
Y\end{array}$ & $6 / 17 / 97-$ & & & $\begin{array}{l}\text { LEL: } \\
\text { O2: }\end{array}$ & BY-109 \\
\hline $\begin{array}{l}97-04398 \\
97-1076 \\
\mathrm{~N}\end{array}$ & $\begin{array}{l}8 / 13 / 97-19: 55 \\
8 / 14 / 97- \\
8 / 14 / 97-04: 00\end{array}$ & K.L. Newcomb & & $\begin{array}{l}\text { LEL: } \\
\text { O2: }\end{array}$ & "97-SY-103-1955" is recorded as sampl id on ASR. \\
\hline $\begin{array}{l}98-00508 \\
97-1481 \\
N\end{array}$ & $\begin{array}{l}10 / 29 / 97-17: 45 \\
10 / 30 / 97- \\
10 / 30 / 97-09: 39\end{array}$ & $\begin{array}{l}\text { K.L. Newcomb } \\
\text { R.E. Brinson }\end{array}$ & $\begin{array}{l}\text { SX-106, R-6 } \\
\text { (Ar) } \\
\text { [ASR, CoC, CFE Log] }\end{array}$ & $\begin{array}{l}\text { LEL: } \\
\text { O2: }\end{array}$ & $\begin{array}{l}\text { "SX106-102997-1747" is recorded as sample id on ASR. } \\
\text { "Drill String Grab } \square \text { is also recorded as sample description } \\
\text { on ASR and as a comment on CoC. }\end{array}$ \\
\hline
\end{tabular}




\subsection{Atmosphere Data}

Table 8.3.a: Data Used as "Air Standard"

\begin{tabular}{|c||c|c|c|c|}
\hline \multicolumn{4}{|c|}{ U.S. Standard Atmosphere $(99.99 \%$} & Composition \\
\hline Components & $\mathrm{N} 2$ & $\mathrm{O} 2$ & $\mathrm{Ar}$ & $\mathrm{CO} 2$ \\
\hline Vol.\% & 78.08 & 20.95 & 0.934 & 0.033 \\
\hline $\begin{array}{c}\text { Useful } \\
\text { Ratios: }\end{array}$ & & & & \\
\hline 1/N2 & 1 & & & \\
\hline 1/O2 & 3.726 & 1 & 0.045 & 0.002 \\
\hline 1/Ar & 83.96 & & 1 & 0.035 \\
\hline
\end{tabular}

Table 8.3.b: Uncertainties in Atmospheric Scaling

\begin{tabular}{|c|c|c|c|}
\hline \multicolumn{4}{|c|}{ PNNL / Mass Spec "Air Standard" Results } \\
\hline Components & N2 & $\mathrm{O} 2$ & $\mathrm{Ar}$ \\
\hline Vol.\% & $77.96+/-0.15$ & $21.04+/-0.17$ & $0.933+/-0.015$ \\
\hline \multicolumn{4}{|l|}{ Calculated Ratios: } \\
\hline $1 / \mathrm{N} 2$ & 1 & & \\
\hline $1 / \mathrm{O} 2$ & $3.705+/-0.03$ & 1 & $0.044+/-0.001$ \\
\hline $1 / \mathrm{Ar}$ & $83.56+/-1.36$ & & 1. \\
\hline \multicolumn{4}{|c|}{ Measured Volumes per Mole at STP } \\
\hline Molar Vol. (L) & 22.40 & 22.40 & 22.09 \\
\hline$\%$ Diff. From 22.415 & 0.04 & 0.04 & 1.43 \\
\hline \multicolumn{4}{|c|}{ Critical Temperatures } \\
\hline Temp(in deg. C) & -147 & -118 & -122 \\
\hline
\end{tabular}




\subsection{Adjusted DS Data Tables}

\section{Table 8.4.a: Adjusted DS Data for Ar-Purge Cases}

Final Results for Drill String Gas Data -- Ar-Purged Cases, Part 1

\begin{tabular}{|c|c|c|c|c|c|c|c|c|c|c|c|c|}
\hline Tank/Riser & S-107 & R-2 & B-203 & $\mathrm{R}-6$ & AW-I01 & & AN-104 & $\mathrm{R}-10 \mathrm{~A}$ & AN-103 & $\mathrm{R}-12 \mathrm{~A}$ & $\mathrm{~S}-106$ & R-7 \\
\hline ALO No. & $95-09000$ & & $96-01330$ & & 96-03482 & & $96-06694$ & & 96-06721 & & $97-01967$ & \\
\hline Analyzed & $9 / 27 / 95$ & & $11 / 20 / 95$ & & $2 / 28 / 96$ & & $9 / 13 / 96$ & & $9 / 17 / 96$ & & $2 / 25 / 97$ & \\
\hline Sampled & $9 / 27 / 95$ & & $11 / 17 / 95$ & & $2 / 27 / 96$ & & $9 / 12 / 96$ & & $9 / 16 / 96$ & & $2 / 25 / 97$ & \\
\hline Purge Gas & $\mathrm{Ar}$ & & $\mathrm{Ar}$ & & $\mathrm{Ar}$ & & $\mathrm{Ar}$ & & $\mathrm{Ar}$ & & $\mathrm{Ar}$ & \\
\hline \multicolumn{13}{|c|}{ Sum of Unaltered Non-Waste Amounts, $\mathrm{G}=\mathrm{O} 2+\mathrm{Ar}+\mathrm{He}$ (\%mole fractions) } \\
\hline $\mathrm{G}$ & 21.14 & & 19.76 & & 19.41 & & 52.4 & & 45.5 & & 20.38 & \\
\hline \multicolumn{13}{|c|}{ Atmospheric Ar \& N2 (\%mole fractions) } \\
\hline AR from $\mathrm{O} 2$ & $9.01 \mathrm{E}-1$ & & $8.38 \mathrm{E}-1$ & & $8.25 \mathrm{E}-1$ & & $3.26 \mathrm{E}-1$ & & $4.10 \mathrm{E}-1$ & & $7.72 \mathrm{E}-1$ & \\
\hline $\mathrm{N} 2$ from $\mathrm{O} 2$ & $7.53 \mathrm{E}+1$ & & $7.01 \mathrm{E}+1$ & & $6.89 \mathrm{E}+1$ & & $2.72 \mathrm{E}+1$ & & $3.43 \mathrm{E}+1$ & & $6.45 \mathrm{E}+1$ & \\
\hline \multicolumn{13}{|c|}{ Non Atm. Ar $=\mathrm{Ar}-\mathrm{Atm} . \mathrm{Ar} \& \mathrm{Non}$ Atm. $\mathrm{N} 2=\mathrm{N} 2-\mathrm{Atm} . \mathrm{N} 2(\%$ mole fractions) } \\
\hline NAtm. Ar & $3.91 \mathrm{E}-2$ & & $1.22 \mathrm{E}-1$ & & $8.49 \mathrm{E}-2$ & & $4.48 \mathrm{E}+1$ & & $3.59 \mathrm{E}+1$ & & $8.84 \mathrm{E}-2$ & \\
\hline NAtm.N2 & $2.71 \mathrm{E}+0$ & & $9.83 \mathrm{E}+0$ & & $8.45 \mathrm{E} \div 0$ & & $1.10 \mathrm{E}+1$ & & $9.51 \mathrm{E}+0$ & & $7.22 \mathrm{E}+0$ & \\
\hline \multicolumn{13}{|c|}{ Mole Fraction Normalization Correction Factor, $\mathrm{NCF}=1-(\mathrm{G}+\mathrm{Atm} . \mathrm{N} 2) / 100$} \\
\hline NCF & $3.57 \mathrm{E}-2$ & & $1.02 \mathrm{E}-1$ & & $1.16 \mathrm{E}-1$ & & $2.04 \mathrm{E}-1$ & & $2.02 \mathrm{E}-1$ & & $1.51 \mathrm{E}-1$ & \\
\hline \multicolumn{13}{|c|}{ Final Adjusted \% Mole Fractions : = (Orig.\%MF-NonWaste.\%MF)/NCF } \\
\hline$\overline{\mathrm{CO} 2}$ & $1.45 \mathrm{E}+0$ & & $2.75 \mathrm{E}-1$ & & $\overline{\mathrm{na}}$ & & na & & "na & & na & \\
\hline $\mathrm{CO}$ & na & & na & & na & & na & & na & & na & \\
\hline $\mathrm{H} 2$ & $1.90 \mathrm{E}+1$ & 5.0 & $3.10 \mathrm{E}+0$ & 5.0 & $2.54 \mathrm{E}+1$ & 5.0 & $3.33 \mathrm{E}+1$ & 5.0 & $4.75 \mathrm{E}+1$ & 5.0 & $4.17 \mathrm{E}+1$ & 5.0 \\
\hline $\mathrm{CH} 4$ & $3.08 \mathrm{E}-2$ & & $1.97 \mathrm{E}-3$ & & na & & $8.97 \mathrm{E}-1$ & & $2.03 \mathrm{E}-1$ & & na & \\
\hline $\mathrm{N} 2$ & $7.59 \mathrm{E}+1$ & 5.0 & $9.67 \mathrm{E}+1$ & 5.0 & $7.26 \mathrm{E}+1$ & 5.0 & $5.39 \mathrm{E}+1$ & 5.0 & $4.71 \mathrm{E}+1$ & 5.0 & $4.77 \mathrm{E}+1$ & 5.0 \\
\hline $\mathrm{N} 2 \mathrm{O}$ & $2.52 \mathrm{E}+0$ & 5.0 & na & & $2.03 \mathrm{E}+0$ & 5.0 & $1.12 \mathrm{E}+1$ & 5.0 & $5.15 \mathrm{E}+0$ & 5.0 & $1.04 \mathrm{E}+1$ & 5.0 \\
\hline Other NOx & $\mathrm{na}$ & & na & & na & & na & & na & & na & \\
\hline $\mathrm{C} 2 \mathrm{Hx}$ & na & & na & & na & & $5.10 \mathrm{E}-1$ & & $2.33 \mathrm{E}-1$ & & $1.39 \mathrm{E}-1$ & \\
\hline Other CxHy & $\mathrm{na}$ & & na & & na & & $4.90 \mathrm{E}-2$ & & $9.90 \mathrm{E}-2$ & & $9.91 \mathrm{E}-2$ & \\
\hline NH3 (est.) & na & & na & & $\mathrm{na}$ & & na & & na & & na & \\
\hline SUM & $9.90 \mathrm{E}+1$ & & $1.00 \mathrm{E}+2$ & & $1.00 \mathrm{E}+2$ & & $9.99 \mathrm{E}+1$ & & $1.00 \mathrm{E}+2$ & & $1.00 \mathrm{E}+2$ & \\
\hline
\end{tabular}


Table 8.4.b: Adjusted DS Data for Ar-Purge Cases (continued)

Final Results for Drill String Gas Data -Ar-Purged Cases, Part 2

\begin{tabular}{|c|c|c|c|c|c|c|}
\hline Tank/ Riser & S-106 & R-7 & BY-109 & SY-102 & SX-106 & R-6 \\
\hline $\begin{array}{l}\text { ALO No. } \\
\text { Analyzed } \\
\text { Sampled } \\
\text { Purge Gas }\end{array}$ & $\begin{array}{c}97-02124 \\
3 / 3 / 97 \\
2 / 25 / 97 \\
\text { Ar }\end{array}$ & & $\begin{array}{c}97-03541 \\
6 / 17 / 97 \\
6 / 17 / 97 \\
\mathrm{Ar} \\
\end{array}$ & $\begin{array}{c}97-04398 \\
8 / 14 / 97 \\
8 / 13 / 97 \\
\mathrm{Ar} \\
\end{array}$ & $\begin{array}{c}98-00508 \\
10 / 30 / 97 \\
10 / 29 / 97 \\
\mathrm{Ar}\end{array}$ & $\cdot$ \\
\hline \multicolumn{7}{|c|}{ Sum of Unaltered Non-Waste Amounts, $\mathrm{G}=\mathrm{O} 2+\mathrm{Ar}+\mathrm{He}$ (\%mole fractions) } \\
\hline G & 83.56 & & 20.07 & 21.8 & 15.16 & \\
\hline \multicolumn{7}{|c|}{ Atmospheric Ar \& N2 (\%mole fractions) } \\
\hline AR from $\mathrm{O} 2$ & $1.08 \mathrm{E}-1$ & & $8.47 \mathrm{E}-1$ & $6.24 \mathrm{E}-1$ & $6.11 \mathrm{E}-1$ & \\
\hline $\mathrm{N} 2$ from $\mathrm{O} 2$ & $9.06 \mathrm{E}+0$ & & $7.08 \mathrm{E}+1$ & $5.22 \mathrm{E}+1$ & $5.11 \mathrm{E}+1$ & \\
\hline
\end{tabular}

Non Atm. Ar = Ar - Atm.Ar \& Non Atm. N2 = N2 - Atm.N2 (\%mole fractions)

\begin{tabular}{|lcccc|}
\hline NAtm. Ar & $8.09 \mathrm{E}+1$ & $5.26 \mathrm{E}-2$ & $7.18 \mathrm{E}+0$ & $3.89 \mathrm{E}-1$ \\
NAtm.N2 & $1.74 \mathrm{E}+0$ & $5.19 \mathrm{E}+0$ & $2.52 \mathrm{E}+1$ & $3.26 \mathrm{E}+1$ \\
\hline & Mole Fraction & Normalization Correction Factor, NCF $=1-(\mathrm{G}+$ Atm. N2) $/ 100$ \\
\hline $\mathrm{NCF}$ & $7.39 \mathrm{E}-2$ & $9.12 \mathrm{E}-2$ & $2.60 \mathrm{E}-1$ & $3.38 \mathrm{E}-1$ \\
\hline
\end{tabular}

Final Adjusted \% Mole Fractions : =(Orig.\%MF-NonWaste.\%MF)/NCF)

\begin{tabular}{|c|c|c|c|c|c|c|c|c|}
\hline $\mathrm{CO} 2$ & $1.76 \mathrm{E}-1$ & & $\mathrm{Na}$ & & $2.31 \mathrm{E}-1$ & & $1.21 \mathrm{E}-1$ & \\
\hline $\mathrm{CO}$ & na & & na & & na & & na & \\
\hline $\mathrm{H} 2$ & $6.49 \mathrm{E}+1$ & 5.0 & $3.24 \mathrm{E}+1$ & 5.0 & $2.42 \mathrm{E}+0$ & 5.0 & $2.31 \mathrm{E}+0$ & 5.0 \\
\hline $\mathrm{CH} 4$ & $1.76 \mathrm{E}-1$ & & $5.70 \mathrm{E}-1$ & & $1.54 \mathrm{E}-2$ & & $1.48 \mathrm{E}-2$ & \\
\hline $\mathrm{N} 2$ & $2.36 \mathrm{E}+1$ & 5.0 & $5.69 \mathrm{E}+1$ & 5.0 & $9.69 \mathrm{E}+1$ & 5.0 & $9.66 \mathrm{E}+1$ & 5.0 \\
\hline $\mathrm{N} 2 \mathrm{O}$ & $1.03 \mathrm{E}+1$ & 5.0 & $9.65 \mathrm{E}+0$ & 5.0 & $3.07 \mathrm{E}-1$ & 5.0 & $9.24 \mathrm{E}-1$ & 5.0 \\
\hline Other NOx & na & & na & & na & & na & \\
\hline $\mathrm{C} 2 \mathrm{Hx}$ & $1.35 \mathrm{E}-1$ & & na & & na & & na & \\
\hline Other CxHy & $6.77 \mathrm{E}-2$ & & $1.10 \mathrm{E}+0$ & & na & & na & \\
\hline NH3 (est.) & na & & na & & na & & na & \\
\hline
\end{tabular}


Table 8.4.c: Adjusted DS Data for $\mathrm{N}_{2}$-Purge Cases

Final Results for Drill String Gas Data - N2-Purged Cases

\begin{tabular}{|l|c|c|c|c|c|c|c|c|c|c|c|c|c|c|}
\hline Tank/Riser & BY-110 & N/R & U-109 & N/R & U-109 & R-2 & S-102 & N/R & U-109 & R-7 & S-102 & R-14 \\
ALO No. & $96-00695$ & & $96-02338$ & & $96-02453$ & & $96-02800$ & & $96-02859$ & & $96-03279$ & \\
Analyzed & $10 / 26 / 95$ & & $12 / 28 / 95$ & & $1 / 4 / 96$ & & $1 / 15 / 96$ & & $1 / 17 / 96$ & & $2 / 16 / 96$ & \\
Sampled & $10 / 24 / 95$ & & $12 / 28 / 95$ & & $1 / 4 / 96$ & & $1 / 12 / 96$ & & $1 / 16 / 96$ & & $2 / 9 / 96$ & \\
Purge Gas & N2 & & N2 & & N2 & & N2 & & N2 & & N2 & \\
\hline
\end{tabular}

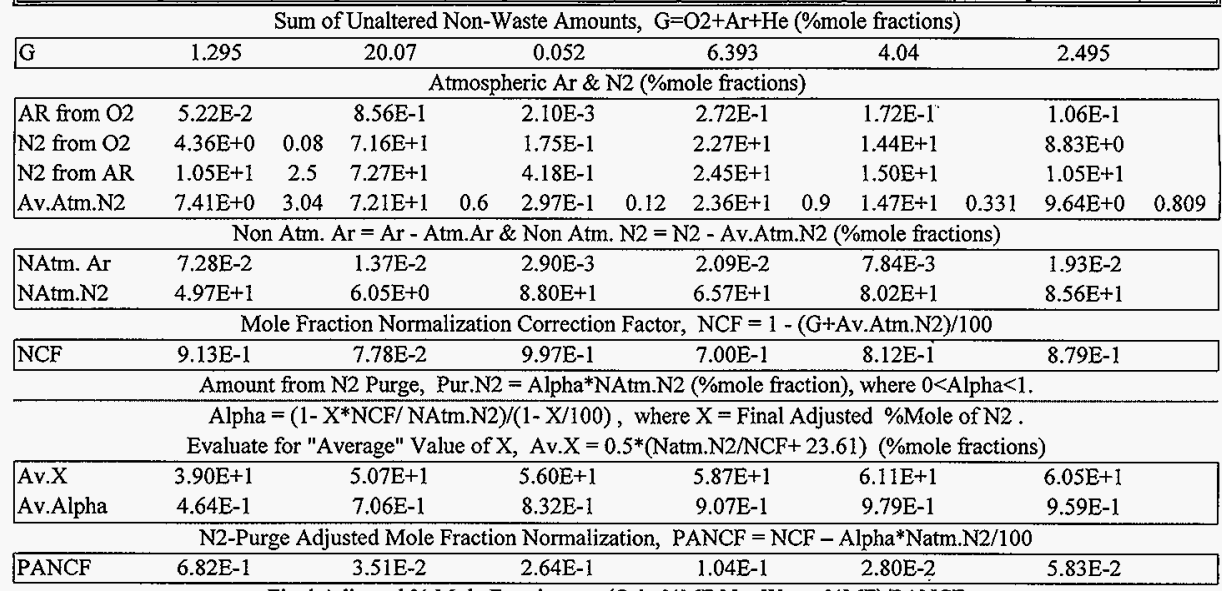

Final Adjusted \% Mole Fractions : =(Orig.\%MF-NonWaste.\%MF)/PANCF

\begin{tabular}{|c|c|c|c|c|c|c|c|c|c|c|c|c|}
\hline $\mathrm{CO} 2$ & na & & $1.74 \mathrm{E}+0$ & & na & & na & & na & & $\overline{\text { na }}$ & \\
\hline $\mathrm{CO}$ & na & & na & & na & & na & & na & & na & \\
\hline $\mathrm{H} 2$ & $3.52 \mathrm{E}+1$ & 8.89 & $4.10 \mathrm{E}+1$ & 22.5 & $2.34 \mathrm{E}+1$ & 17.2 & $2.58 \mathrm{E}+1$ & 21.9 & $2.32 \mathrm{E}+1$ & 22.4 & $3.67 \mathrm{E}+1$ & 34.2 \\
\hline $\mathrm{CH} 4$ & $1.22 \mathrm{E}+0$ & & $1.71 \mathrm{E}-1$ & & 3.02E-1 & & $2.01 \mathrm{E}-1$ & & $3.92 \mathrm{E}-1$ & & na & \\
\hline N2 & $3.90 \mathrm{E}+1$ & 15.4 & $5.07 \mathrm{E}+1$ & 27.1 & $5.60 \mathrm{E}+1$ & 32.4 & $5.87 \mathrm{E}+1$ & 35.1 & $6.11 \mathrm{E}+1$ & 37.5 & $6.05 \mathrm{E}+1$ & 36.9 \\
\hline $\mathrm{N} 2 \mathrm{O}$ & $2.18 \mathrm{E}+1$ & 5.52 & $7.98 \mathrm{E}+0$ & 4.38 & $2.00 \mathrm{E}+1$ & 14.7 & $1.54 \mathrm{E}+1$ & 13.1 & $1.51 \mathrm{E}+1$ & 14.6 & $2.98 \mathrm{E}+0$ & 2.78 \\
\hline Other Nox & na & & na & & $1.89 \mathrm{E}-1$ & & na & & na & & na & \\
\hline $\mathrm{C} 2 \mathrm{Hx}$ & $1.63 \mathrm{E}+0$ & & na & & $7.56 \mathrm{E}-2$ & & na & & na & & na & \\
\hline Other $\mathrm{CxHy}$ & $8.94 \mathrm{E}-1$ & & na & & na & & na & & na & & na & \\
\hline NH3 (est.) & $4.10 \mathrm{E}-1$ & & na & & na & & na & & na & & na & \\
\hline SUM & $1.00 \mathrm{E}+2$ & & $1.02 \mathrm{E}+2$ & & $1.00 \mathrm{E}+2$ & & $1.00 \mathrm{E}+2$ & & $9.98 \mathrm{E}+1$ & & $1.00 \mathrm{E}+2$ & \\
\hline
\end{tabular}




\section{DISTRIBUTION SHEET}

\begin{tabular}{|c|c|c|c|c|c|}
\hline \multirow{2}{*}{\multicolumn{2}{|c|}{$\begin{array}{l}\text { To: } \\
\text { W. B. Barton }\end{array}$}} & \multirow{2}{*}{\multicolumn{2}{|c|}{$\begin{array}{l}\text { From: } \\
\text { E. R. Siciliano }\end{array}$}} & \multicolumn{2}{|l|}{ Page 1 of 1} \\
\hline & & & & \multicolumn{2}{|c|}{ Date: May 4, 1998} \\
\hline \multicolumn{4}{|c|}{ Project Title/Work Order } & \multicolumn{2}{|l|}{ EDT No. 623003} \\
\hline \multicolumn{4}{|c|}{ Drill String Gas Data } & \multicolumn{2}{|l|}{ ECN No. } \\
\hline Name & MSIN & $\begin{array}{c}\text { Text W/All } \\
\text { Attachments }\end{array}$ & Text Only & $\begin{array}{c}\text { Attach./ } \\
\text { Appendix Only }\end{array}$ & $\begin{array}{c}\text { EDT/ECN } \\
\text { Only }\end{array}$ \\
\hline
\end{tabular}

R. P. Anatatmula

R1-30

S. A. Barker

R2-11

W. B. Barton

R2-12

J. M. Bates

K7 -15

R. E. Bauer

S7-14

R. A. Bechtold

K7-22

J. 0. Bingham

R2-11

S. J. Bos

P7-22

D. R. Bratze 1

S7-14

J. W. Brothers

$\mathrm{Kg}-20$

M. Goheen

P7-22

J. M. Grigsby

$57-14$

C. A. Groendyke

S7-54

D. C. Hedengren

R2-11

K. M. Hodgson

R2-11

G. D. Johnson

S7-14

N. W. Kirch

R2-11

J. G. Kristofsky

R2-12

L. Mahoney

$\mathrm{K} 7-15$

D. A. Reynolds

R2-11

G. W. Rosenwald

S7-54

J. S. Schofield

S7-12

E. R. Siciliano

B4-43

$\mathrm{K} 7-15$

C. W. Stewart

R2-12

$x$

$x$

$x(5)$

N. E. Wilkins

$x$

$x$

$x$

$x$

$x$

$x$

$x$

$x$

$x$

$x$

$x$

$x$
$x$

$x$

$x$

$x$

$x$

$x$

$x$

$x$

$X(10)$

$x$

$x$

H. Babad

Babad Technical Services

2540 Cordoba Court

Richland, WA 99352

W. L. Kubic, MS-A150

Los Alamos National Laboratory

Los Alamos, NM 87545

R. J. White, Unit H-21

888181 0?d Highway

Islamorada, FL 33036-3098 